Original paper

\title{
Lithogeochemistry and Sr-Nd isotopic composition of Neoproterozoic metasedimentary rocks of the Teplá Crystalline Complex, western Bohemian Massif: a geotectonic interpretation
}

\author{
Jiří FIALA ${ }^{1 *}$, Friedhelm HENJES-KUNST², Hiltrud MÜLLER-SIGMUND³ ${ }^{3}$ Zdeněk VEJNAR ${ }^{1}$ \\ ${ }^{1}$ Institute of Geology, Academy of Sciences of the Czech Republic, v.v.i., Rozvojová 135, 16502 Prague 6, Czech Republic; \\ fiala@gli.cas.cz \\ 2 Bundesanstalt für Geowissenschaften und Rohstoffe, Geozentrum Hannover, Stilleweg 230655 Germany \\ ${ }^{3}$ Institut für Geo- und Umweltnaturwissenschaften, Universität Freiburg in Breisgau, Tannenbacher Str. 4, 79106 Germany \\ * Corresponding author
}

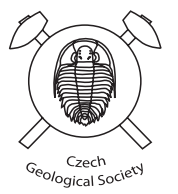

Clastic metasedimentary rocks from the Teplá Crystalline Complex (western Bohemian Massif) were analysed for major and trace elements, $\mathrm{Sr}$ and Nd isotopes. The metamorphic grade of these rocks of presumed Neoproterozoic protolith age increases from SE to NW from very low-grade to amphibolite-facies conditions. Geochemistry indicates that the sedimentary protoliths for the whole sequence consisted of immature (pelitic) greywackes chiefly derived from an ensialic island arc. No significant changes in composition from the lowest to the highest grade or across the strike of isograds were observed. Chemical variations between original slates and greywackes within a single locality often considerably exceed the variation among samples of different metamorphic grades or of different geographic positions. The prevailing REE spectra with distinct negative Eu anomalies show a close similarity with those of modern turbidites from ensialic island arcs. Several samples without any Eu anomaly resemble the REE patterns of less differentiated island arc andesites. LREE leaching under oxidizing conditions is suggested by several REE patterns with positive Ce anomalies. The Sm-Nd model ages $\mathrm{T}_{\mathrm{DM}}$ of samples with Ce positive anomalies are higher $\left(\mathrm{T}_{\mathrm{DM}} 1.8-2.0 \mathrm{Ga}\right)$ than those of all other samples $\left(\mathrm{T}_{\mathrm{DM}}=1.1-1.5 \mathrm{Ga}\right)$. Initial $\mathrm{Sr}$ isotopic ratios for all samples are fairly constant and compatible with an assumed dominance of isotopically less evolved detrital material. Geochemical characteristics of the clastic metasediments of the Teplá Crystalline Complex are thus consistent with a model of incorporation and preservation of arc-derived sediments in a Cadomian accretionary wedge.

Keywords: metasedimentary rocks, geochemistry, Sr-Nd isotopes, provenance, Teplá Crystalline Complex, Bohemian Massif Received: 13 February 2014; accepted: 12 November 2014; handling editor: J. Žák

\section{Introduction}

Geodynamic models for the crystalline basement in the western Bohemian Massif concentrated mostly on reconstructing the Variscan convergence of separate geological units since the pioneering work of Weber and Behr (1983). A lithogeochemical approach to the study of selected metapsammopelitic lithologies in the Bohemian Massif (Jakeš et al. 1979; Mrázek 1984; Čadková and Mrázek 1987; Matějka 1988) as in other segments of the Variscan orogen (Müller 1989; Wimmenauer 1991) supplied initial valuable comparative data. Several detailed structural (Hajná et al. 2010, 2013) and lithogeochemical (Drost at al. 2004, 2007) studies of the Barrandian unmetamorphosed or anchimetamorphosed Neoproterozoic sediments and volcanics appeared in the last decade. However, no systematic studies in lithogeochemistry as yet exist in the low- to high-metamorphosed western part of the Teplá-Barrandian Unit, referred to as the Teplá Crystalline Complex (TCC).

The results of the present studies on metapelites and metapsammites of the TCC allow a comparison with data on similar rocks of the adjacent sequences of Barrandian Neoproterozoic on the one hand and with its presumed tectonometamorphic equivalent, the Erbendorf-Vohenstrauß Zone (ZEV), on the other. The ZEV is a mediumpressure unit positioned at the westernmost border of the Bohemian Massif in which the KTB superdeep borehole was located (Weber and Vollbrecht 1986).

\section{Geology and metamorphism of the Teplá Crystalline Complex}

The TCC represents a segment of Neoproterozoic rocks comparable to those of the Barrandian area, but affected by medium-pressure regional metamorphism. In the SE, the boundary of the TCC against the Barrandian Neoproterozoic is conventionally set to the biotite isograd (Fig. 1). The NW boundary of the TCC usually defines the SE termination of the Mariánské Lázně Complex (MLC), delineated by a continuous amphibolite band. In the $\mathrm{N}$, the MLC is thrust over low-pressure/medium- 


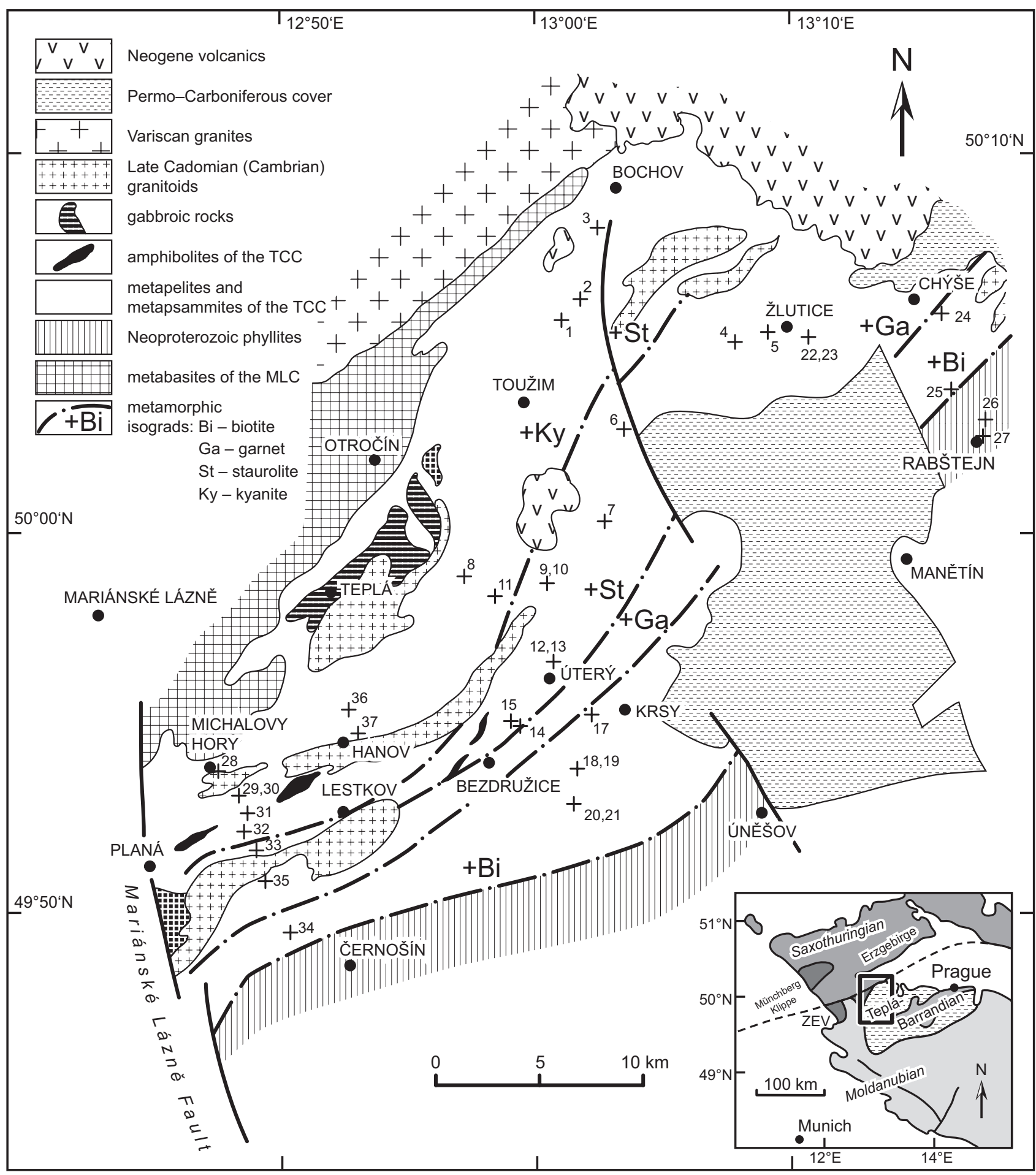

Fig. 1 Sample location and geology of the studied part of the TCC, for orientation see inset. Numbered points correspond to those in Tab. 1

temperature Saxothuringian metamorphic rocks (Kachlík 1993, 1994). The MLC thus forms the boundary between the Saxothuringian and the Teplá-Barrandian units. A similar but less distinct tectonic contact exists in the SE, where medium-pressure metamorphic rocks of the TCC are thrust toward the NW over metagabbros and am- phibolites of the MLC (Matte et al. 1990; Zulauf 1997). Beard et al. (1995) interpreted the MLC as an exotic metaophiolite unit with its own specific lithological and metamorphic characteristics. Its emplacement is believed to have occurred during the Variscan collision between the Saxothuringian and Teplá-Barrandian units. This concept 
was challenged by Štědrá et al. (2002) and Timmermann et al. $(2004,2006)$. The former study examined coronitic metagabbros occurring as minor bodies within the MLC and in the paragneiss and orthogneiss of the TCC. Some metagabbros caused contact metamorphism of the host rocks, and their emplacement age of $496 \pm 1 \mathrm{Ma}$ (Bowes and Aftalion 1991) documents the juxtaposition of the MLC and TCC prior to late Cambrian times. The latter studies obtained $\mathrm{U}-\mathrm{Pb}$ zircon ages from the MLC rocks, which fall into two age groups, c. $540 \mathrm{Ma}$ and c. 380 Ma. The late Cadomian age was interpreted to reflect the crystallization of the MLC oceanic protolith whereas the latter one reflects the Variscan metamorphism and decompression melting. Regional metamorphism of the TCC shows a distinct NW-oriented gradient (Kratochvíl et al. 1951) defined by tectonically reduced biotite, garnet, staurolite and kyanite zones (Fig. 1). Recent studies of the metamorphic evolution distinguished both Cadomian and Variscan Barrovian-type metamorphic overprints:

(1) To the NW of the staurolite isograd, the Cambrian granitoids have been pervasively deformed into the mylonitic Teplá and Hanov orthogneisses (Zulauf 1997; Dörr et al. 1998), whereas the Lestkov granitoid, largely situated in the garnet zone, does not show a pervasive mylonitic fabric.

(2) Variscan garnet developed in pressure shadows behind Cadomian garnet (Zulauf 1997).

(3) Variscan kyanite replaces andalusite in early Ordovician pegmatites (Žáček 1994; Glodny et al. 1998).

(4) Staurolite replaces cordierite in the northern contact aureole of the Lestkov granitoid (Cháb and Žáček 1994), indicating that the staurolite isograd reflects the Variscan cycle.

(5) The ${ }^{39} \mathrm{Ar}-{ }^{40} \mathrm{Ar}$ and $\mathrm{K}-\mathrm{Ar}$ dating of hornblende and white mica from the TCC yielded ages of $383 \mathrm{Ma}$ and 366-371 Ma, respectively (Kreuzer et al. 1992; Dallmeyer and Urban 1998). Hornblende ages suggest a Devonian temperature of more than $c .500^{\circ} \mathrm{C}$ for the northwestern part of the TCC, assuming such a closure temperature for the $\mathrm{K}-\mathrm{Ar}$ isotopic system of hornblende (Zulauf et al. 2004).

Investigations into the crystallization-deformation relationships in the TCC indicate that the biotite and garnet isograds of Cháb and Žáček (1994) (Fig. 1) reflect the Cadomian orogeny, whereas the staurolite and kyanite isograds are Variscan in age. Variscan biotite and garnet appear immediately to the NW of the Cadomian garnet isograd. To the $\mathrm{SE}$ of the garnet isograd, the Variscan deformation occurred under retrograde metamorphic conditions as compared to the Cadomian fabrics (Zulauf et al. 2004).

\section{Lithology, lithostratigraphy and age of the Teplá Crystalline Complex}

The existing knowledge of the lithology of the TCC protolith is mostly based on geological mapping (Vejnar et al. 1962) and studies of metamorphic processes (Žáček and Cháb 1993; Cháb and Žáček 1994) and is further expanded by this paper.

The dominant lithological type are finely laminated psammo-pelitic rhythmites with isolated slaty greywacke bodies and rare greywackes that form alternating bodies tens of centimeters to meters in thickness. The absence of thicker greywacke bodies, the scarcity of basic volcaniclastic sediments (Fig. 1) and only an isolated occurrence of black shales suggest an originally lithologically monotonous succession (Holubec 1966).

Lithostratigraphic correlation of the TCC with the Barrandian Neoproterozoic is only conventional. It is supported by a similar lithofacies development of the two units, particularly along their contact, i.e., along the biotite isograd. Although various lithostratigraphic schemes have been proposed for the Barrandian Neoproterozoic, including the TCC (Kettner 1917; Röhlich 1965; Holubec 1966; Cháb and Pelc 1968, 1973; Cháb 1978; Mašek and Zoubek 1980; Kř́bek et al. 2000; Mašek 2000; Röhlich 2000; Lang 2000), recent studies of Hajná et al. (2010, 2011, 2012 and 2013) suggested that the central and NW parts of the TepláBarrandian unit represent a fragment of an accretionary wedge of the Avalonian-Cadomian belt, which developed along the northern active margin of Gondwana during the Late Neoproterozoic. This interpretation implies that the various component units (commonly fault-bounded) of the presumed wedge may not exhibit mutual stratigraphic relationships as straightforward as previously thought. Nevertheless, the TCC can be correlated with a lithologically similar NW part of the Barrandian Neoproterozoic, referred to as the Kralovice-Rakovník Belt (Röhlich 1965; Hajná et al. 2010, 2011), with the difference being that the TCC is progressively metamorphosed up to the amphibolite facies.

The age constraints for the TCC metasedimentary rocks are the emplacement ages of the metagranitoids and metapegmatites. The TCC Cambrian (meta-)granitoids (the Lestkov Massif, the Teplá and Hanov orthogneisses) yielded $\mathrm{U}-\mathrm{Pb}$ zircon intrusive ages of $c$. $513 \mathrm{Ma}$ (Dörr et al. 1998), the metapegmatites gave $\mathrm{U}-\mathrm{Pb}$ columbite, garnet, monazite and zircon as well as $\mathrm{Rb}-\mathrm{Sr}$ muscovite ages of c. 480 Ma (Košler et al. 1997; Glodny et al. 1998). These data thus provide an upper limit for age of deposition of metasedimentary rocks of the TCC, most probably pointing to Neoproterozoic to early Cambrian. Paper by Dörr et al. (2002) summarized the geochronological evolution of the Teplá-Barrandian Unit in early Cambrian to Neoproterozoic times.

\section{Methods and sample description}

The TCC metasedimentary rocks were sampled along a cross-section from very low-grade chlorite-sericite 
Tab. 1 List of samples with their WGS coordinates

\begin{tabular}{|c|c|c|c|c|c|}
\hline No. & Description & Variety & Location & $\mathbf{N}$ & $\mathbf{E}$ \\
\hline 1 & Two-mica paragneiss with Grt, Ky and Sil & $\mathrm{shl} / \mathrm{shl}$ & $\begin{array}{l}\text { Abandoned quarry in a weekend-house settlement } 1.5 \mathrm{~km} \\
\text { NNE of Kojšovice }\end{array}$ & 50.0923 & 13.0136 \\
\hline 2 & $\begin{array}{l}\text { Two-mica paragneiss with Grt, Ky and Pl } \\
\text { porphyroblasts }\end{array}$ & grw/grw & Roadcut at the Toužim-Bochov road, S periphery of Kozlov & 50.1034 & 13.0256 \\
\hline 3 & $\begin{array}{l}\text { Two-mica paragneiss with Grt and micace- } \\
\text { ous stripes }\end{array}$ & grw/grw & $\begin{array}{l}\text { Rocky outcrop in the valley of the Bochov Stream, } 3 \mathrm{~km} \\
\text { SSW of Bochov }\end{array}$ & 50.1320 & 13.0376 \\
\hline 4 & Muscovite-rich paragneiss with Grt and Chl & $\mathrm{shl} / \mathrm{shl}$ & Rocky outcrops below the dam W of Žlutice & 50.0854 & 13.1291 \\
\hline 5 & Two-mica paragneiss with Grt and Chl & $\mathrm{shl} / \mathrm{shl}$ & $\begin{array}{l}\text { Rocky outcrops in the valley of Střela River } 0.5 \mathrm{~km} \mathrm{~W} \\
\text { of Žlutice }\end{array}$ & 50.0876 & 13.1504 \\
\hline 6 & Micaschist with Grt & grw/grw & $\begin{array}{l}\text { Outcrop on the elevation } 1 \mathrm{~km} \mathrm{~S} \text { of the Smilov railway } \\
\text { station E of Toužim }\end{array}$ & 50.0445 & 13.0515 \\
\hline 7 & Micaschist with Grt, St and Pl poikiloblasts & grw/grw & Outcrop $2 \mathrm{~km} \mathrm{NW}$ of Bezvěrov at the road to Toužim & 50.0080 & 13.0374 \\
\hline 8 & $\begin{array}{l}\text { Two-mica paragneiss with Grt, St, Ky and Pl } \\
\text { poikiloblasts }\end{array}$ & $\mathrm{shl} / \mathrm{grw}$ & Outcrop $0.8 \mathrm{~km}$ E of Dobrá Voda E of Teplá & 49.9885 & 12.9512 \\
\hline 9 & Biotite-rich micaschist with Grt & grw/grw & $\begin{array}{l}\text { Quarry on elevation } 1.5 \mathrm{~km} \mathrm{~S} \text { of Branišov above the Úterý } \\
\text { Stream valley }\end{array}$ & 49.9781 & 12.9970 \\
\hline 10 & Micaschist with Grt and St & $\mathrm{shl} / \mathrm{shl}$ & For the location see No. 9 & 49.9781 & 12.9970 \\
\hline 11 & Micaschist with Grt and St & $\mathrm{shl} / \mathrm{shl}$ & Roadcut of the forest road $1 \mathrm{~km} \mathrm{NW}$ of Vidžín & 49.9768 & 12.9708 \\
\hline 12 & $\begin{array}{l}\text { Biotite micaschist with Grt, prh and graphite } \\
\text { substance }\end{array}$ & grw/grw & $\begin{array}{l}\text { Outcrop on the N periphery of Úterý, left bank of the Úterý } \\
\text { Stream }\end{array}$ & 49.9430 & 13.0039 \\
\hline 13 & Micaschist with Grt and St & $\mathrm{shl} / \mathrm{shl}$ & For the location see No.12 & 49.9430 & 13.0039 \\
\hline 14 & Micaschist with Grt & $\mathrm{shl} / \mathrm{shl}$ & Roadcut $2 \mathrm{~km} \mathrm{SSW}$ of Úterý at the road to Bezdružice & 49.9207 & 12.9898 \\
\hline 15 & $\begin{array}{l}\text { Biotite micaschist with Grt, Po and graphite } \\
\text { substance }\end{array}$ & grw/grw & Outcrop $2.5 \mathrm{~km} \mathrm{SSW}$ of Úterý at the road to Bezdružice & 49.9210 & 12.9851 \\
\hline 17 & $\begin{array}{l}\text { Phyllite with Bt, Qtz clasts and volcanics } \\
\text { fragments }\end{array}$ & grw/grw & $\begin{array}{l}\text { Outcrop at the road between Úterý and Krsy in the Dolský } \\
\text { Stream valley }\end{array}$ & 49.9221 & 13.0306 \\
\hline 18 & Phyllite with Bt & $\mathrm{shl} / \mathrm{shl}$ & $\begin{array}{l}\text { Outcrop in the Úterý Stream valley } 1.5 \mathrm{~km} \text { W of Ostrov } \\
\text { near Bezdružice }\end{array}$ & 49.9002 & 13.0216 \\
\hline 19 & Phyllite with Bt and Qtz-Pl clasts & grw/grw & For the location see No.18 & 49.9002 & 13.0216 \\
\hline 20 & Phyllite with sporadic Bt & slt/sltshl/shl & $\begin{array}{l}\text { Outcrop at Starý Mlýn on the Úterý Stream S of the } \\
\text { Krsy-Bezdružice road }\end{array}$ & 49.8880 & 13.0194 \\
\hline 21 & Phyllite with Bt & grw/shl & For the location see No. 20 & 49.8880 & 13.0194 \\
\hline 22 & Micaschist with Grt and Chl & $\mathrm{shl} / \mathrm{shl}$ & Outcrop at the road $1 \mathrm{~km}$ SE of Žlutice & 50.0899 & 13.1742 \\
\hline 23 & Biotite micaschist with Grt & grw/grw & For the location see No. 22 & 50.0899 & 13.1742 \\
\hline 24 & Micaschist with sporadic Grt & $\mathrm{shl} / \mathrm{grw}$ & Outcrop in the Střela River valley $1 \mathrm{~km}$ SE of Chýše & 50.1020 & 13.2635 \\
\hline 25 & Phyllite with sporadic Bt, silky glitter & $\mathrm{shl} / \mathrm{shl}$ & Outcrop in the Střela River valley $0.5 \mathrm{~km}$ ESE of Jablonné & 50.0652 & 13.2747 \\
\hline 26 & Roofing phyllite with Po & $\mathrm{shl} / \mathrm{shl}$ & Abandoned quarry 1 km NE of Rabštejn & 50.0557 & 13.2995 \\
\hline 27 & Roofing phyllite with Po & $\mathrm{shl} / \mathrm{shl}$ & Abandoned quarry at Rabštejn & 50.0471 & 13.2959 \\
\hline 28 & Two-mica paragneiss with Grt, Ky and Sil & $\mathrm{shl} / \mathrm{shl}$ & $\begin{array}{l}\text { Outcrop on the E periphery of Michalovy Hory, left bank } \\
\text { of the Kosí Stream }\end{array}$ & 49.9001 & 12.7911 \\
\hline 29 & Two-mica paragneiss with Grt, Ky and Sil & $\mathrm{shl} / \mathrm{shl}$ & $\begin{array}{l}\text { Outcrop } 2 \mathrm{~km} \text { SE of Michalovy Hory, left bank of the Kosí } \\
\text { Stream }\end{array}$ & 49.8881 & 12.8064 \\
\hline 30 & Two-mica paragneiss with Grt & grw/grw & For the location see No. 29 & 49.8881 & 12.8064 \\
\hline 31 & Two-mica paragneiss with Ky & $\mathrm{shl} / \mathrm{shl}$ & $\begin{array}{l}\text { Outcrop } 3 \mathrm{~km} \mathrm{SE} \text { of Michalovy Hory, left bank of the Kosí } \\
\text { Stream }\end{array}$ & 49.8803 & 12.8105 \\
\hline 32 & Two-mica paragneiss with Grt, St and Ky & $\mathrm{shl} / \mathrm{shl}$ & $\begin{array}{l}\text { Outcrop on the left bank of the Kosí Stream } 3.5 \mathrm{~km} \text { E of } \\
\text { Planá }\end{array}$ & 49.8730 & 12.8097 \\
\hline 33 & Micaschist wit Grt & grw/grw & $\begin{array}{l}\text { Outcrop on the promontory, left bank of the Kosí Stream, } \\
4 \mathrm{~km} \text { E of Planá }\end{array}$ & 49.8683 & 12.8164 \\
\hline 34 & Phyllite with Bt and Qtz-Pl clasts & grw/grw & $\begin{array}{l}\text { Outcrop on left bank of the Kosí Stream at the } \\
\text { Strríbro-Planá road }\end{array}$ & 49.8277 & 12.8402 \\
\hline 35 & $\begin{array}{l}\text { Micaschist with Grt, contact-metamorphozed } \\
\text { to Bt-hornfels }\end{array}$ & grw/grw & $\begin{array}{l}\text { Outcrop on the right bank of the Kosí Stream, E periphery } \\
\text { of Krrínov }\end{array}$ & 49.8538 & 12.8194 \\
\hline 36 & $\begin{array}{l}\text { Two-mica paragneiss with Grt and Ky } \\
\text { nodules }\end{array}$ & $\mathrm{shl} / \mathrm{shl}$ & $\begin{array}{l}\text { Outcrop on the left bank of the Hadovka Stream at the } \\
\text { Lestkov-Teplá road }\end{array}$ & 49.9251 & 12.8761 \\
\hline 37 & Two-mica paragneiss with Grt and Ky & $\mathrm{shl} / \mathrm{shl}$ & $\begin{array}{l}\text { Outcrop on the left bank of the Hadovka Stream } 1 \mathrm{~km} \mathrm{NE} \\
\text { of Hanov }\end{array}$ & 49.9123 & 12.8856 \\
\hline
\end{tabular}

Rock types: shl - metashale, grw - metagreywacke - megascopic classification/chemical classification according to Fig. 2

Mineral abbreviations are after Kretz (1983) 
phyllites to amphibolite-facies kyanite-garnet gneisses (Fig. 1). A total of 36 samples, c. 2-3 kg in weight, were collected from outcrops and quarries. Table 1 contains overview of the rock types, location of sampling sites and their geographic coordinates. Sampled lithologies comprised either metashale (shl) or metagreywacke (grw). The samples were homogenized by standard methods at the Institute of Geology Academy of Sciences of the Czech Republic (AS CR). The XRF analyses for major and trace elements were performed by one of the authors (Müller-Sigmund) on a PHILIPS PW2404 spectrometer at the Institute of Earth and Environmental Sciences, Albert-Ludwig University, Freiburg in Breisgau, Germany, using methods described in Norrish and Chappell (1977). The REE analytical procedure (Povondra et al. 1968) consists in sample decomposition in a mixture of concentrated nitric and hydrofluoric acids. Lanthanide fluorides were converted into perchlorates by repeated evaporation with perchloric acid. Dissolved samples were transferred on ion exchange resin and the REE were selectively eluted, getting rid of other matrix cations. Collected fractions containing lanthanides were analysed by ICP-OES method (P. Foch, Czech Geological Survey, Prague in collaboration with P. Povondra, Faculty of Science, Charles University, Prague).

$\mathrm{The} \mathrm{Rb}-\mathrm{Sr}$ and $\mathrm{Sm}-\mathrm{Nd}$ isotopic determinations were carried out by another author (Henjes-Kunst) at the Federal Institute for Geosciences and Natural Resources (BGR). Sample powders were mixed with ${ }^{87} \mathrm{Rb}-{ }^{84} \mathrm{Sr}$ and ${ }^{147} \mathrm{Sm}-$ ${ }^{148} \mathrm{Nd}$ spikes and dissolved in a micro-wave furnace in a two-steps procedure $\left(1^{\text {st }}\right.$ step: concentrated $\mathrm{HF}-\mathrm{HNO}_{3} ; 2^{\text {nd }}$ step: $6 \mathrm{M} \mathrm{HCl}$ ). Rubidium, $\mathrm{Sr}$, and the lanthanides were separated on standard cation-exchange columns. Samarium and $\mathrm{Nd}$ were isolated from each other and adjacent REE in separate columns using HDEHP-coated Teflon powder (Cerrai and Testa 1963). The isotopic composition of $\mathrm{Rb}$ was measured on a VG-Micro-mass MM30 single-collector mass spectrometer; those of $\mathrm{Sr}, \mathrm{Sm}$ and $\mathrm{Nd}$ on a Finnigan MAT 261 multi-collector mass spectrometer equipped with five Faraday cups. Neodymium isotopic ratios were normalized to ${ }^{146} \mathrm{Nd} /{ }^{144} \mathrm{Nd}=0.7219$ and are reported relative to ${ }^{143} \mathrm{Nd} /{ }^{144} \mathrm{Nd}=0.511860$ for the La Jolla Nd standard. Strontium isotopic ratios were normalized to ${ }^{86} \mathrm{Sr} /{ }^{88} \mathrm{Sr}=$ 0.1194 and are reported relative to ${ }^{87} \mathrm{Sr} /{ }^{86} \mathrm{Sr}=0.710245$

Tab. 2 Major-element data for the Teplá Crystalline Complex metasediments [wt. \%]

\begin{tabular}{|c|c|c|c|c|c|c|c|c|c|c|c|c|c|c|c|c|c|c|}
\hline 0. & 1 & 2 & 3 & 4 & 5 & 6 & 7 & 8 & , & 10 & 11 & 12 & 13 & 14 & 15 & 17 & 18 & 19 \\
\hline $\mathrm{iO}_{2}$ & & & 1.40 & .19 & .81 & & 6 & & & & & & & & & & & 0.07 \\
\hline & & & & & & & & & & & & & & & 0.74 & & & 0.66 \\
\hline & 15.28 & 6.90 & 3.75 & 6.23 & 17.53 & 13.49 & 589 & 2.96 & 583 & 15.74 & 17.23 & 14.09 & 16.93 & 15.29 & 14.90 & & 7.19 & 14.12 \\
\hline $\mathrm{O}(\mathrm{t})$ & 5.35 & 5.56 & 3.82 & 5.44 & 6.11 & 3.80 & 4.88 & 3.68 & 4.69 & 4.63 & 5.47 & 356 & 422 & 377 & 4.13 & & & 4.43 \\
\hline & 0.10 & & & & & & & & & & & & & & 0.04 & & & 0.05 \\
\hline$\alpha \Omega$ & 2.15 & 2.18 & 1.40 & 2.24 & 2.57 & 1.34 & & & & & & & & 1 & 162 & & & 1.87 \\
\hline $\mathrm{O}$ & & & & & 1.00 & & & & & & & & & & & & & 20 \\
\hline 0 & 2.72 & & 3.78 & 2.76 & 2.51 & & & & & & & & & & & & & 323 \\
\hline & & & & & & & & & & & & & & & & & & \\
\hline $\mathrm{O}_{5}$ & & & & & & & & & & & & & & & & & & 0 \\
\hline${ }_{2} \mathrm{O}^{+}$ & & & & & 2.21 & & & & & & & & & & & & & \\
\hline $\mathrm{O}_{2}$ & & & & & & & & & & & & & & & & & & \\
\hline & & & & & & & & & & & & & & & & & & \\
\hline 0. & & & & & & & & & & & & & & & & & & \\
\hline $\mathrm{O}_{2}$ & 0.14 & 0.79 & 4.91 & 4.81 & 64.00 & 65.27 & 62.43 & 2.62 & 1.97 & 70.80 & 73.57 & 61.93 & 65.21 & 66.21 & 64.53 & 63.03 & 65.40 & 64.86 \\
\hline $\mathrm{O}_{2}$ & 81 & & 70 & 76 & 76 & & & & 86 & & 67 & 83 & .76 & .73 & 0.82 & .79 & .84 & 0.76 \\
\hline $1_{2} \mathrm{O}_{3}$ & 18.19 & 18.22 & 16.01 & 16.66 & 16.72 & 17.23 & 16.94 & 17.14 & 18.73 & 14.67 & 12.74 & 18.21 & 17.03 & 15.67 & 15.85 & 16.60 & 16.84 & 17.25 \\
\hline $\mathrm{eO}(\mathrm{t})$ & 6.99 & & 5. & & 57 & & & & & & 3.60 & & 5.81 & 5.08 & 5.42 & & & 5.41 \\
\hline $\mathrm{InO}$ & 0.08 & & & 0.0 & 0.09 & & & & & & & & & & 7 & & & 0.10 \\
\hline $\mathrm{MgO}$ & 2.80 & & 2.48 & 2.17 & 2.35 & 1.8 & & & & & 1.3 & & & & 40 & & & 2.02 \\
\hline $\mathrm{aO}$ & 0 . & & 1.12 & 2.36 & 1.69 & 0.2 & & & & 0.94 & 1.46 & & 0.94 & 2.40 & 1.04 & & & 0.77 \\
\hline $\mathrm{Na}_{2} \mathrm{O}$ & 2.44 & 2.67 & 2.66 & 4.02 & 3.51 & 2.66 & 3.04 & & 2.57 & 2.56 & 3.42 & 3.12 & 2.75 & 3.79 & 5.04 & & & 2.93 \\
\hline $\mathrm{K}_{2} \mathrm{O}$ & 3.48 & 3.40 & 2.69 & 2.13 & 2.46 & 3.27 & 2.88 & & 3.47 & 2.40 & 1.59 & 3.17 & 3.01 & 1.92 & 1.54 & 2.08 & & 3.00 \\
\hline $\mathrm{P}_{2} \mathrm{O}_{5}$ & 0.17 & 0.16 & 0.12 & 0.12 & 0.13 & 0.13 & 0.16 & 0.17 & 0.13 & 0.12 & 0.09 & 0.15 & 0.14 & 0.13 & 0.15 & 0.13 & 0.16 & 0.16 \\
\hline $\mathrm{H}^{+}$ & 3.47 & 3.29 & 2.02 & 1.29 & 1.84 & & 2.70 & & & & & & 1.26 & & & & & 1.47 \\
\hline $\mathrm{CO}_{2}$ & 0.60 & & & & & & & & & & & 0.89 & 0.19 & 0.12 & & & & 0.32 \\
\hline & 99.45 & 99.65 & 99.29 & 99.68 & 99.49 & 99.56 & 99.04 & & 9.14 & 99.36 & 99.16 & 99.73 & 99.48 & 99.25 & 99.03 & 98.64 & 99.61 & 99.05 \\
\hline
\end{tabular}



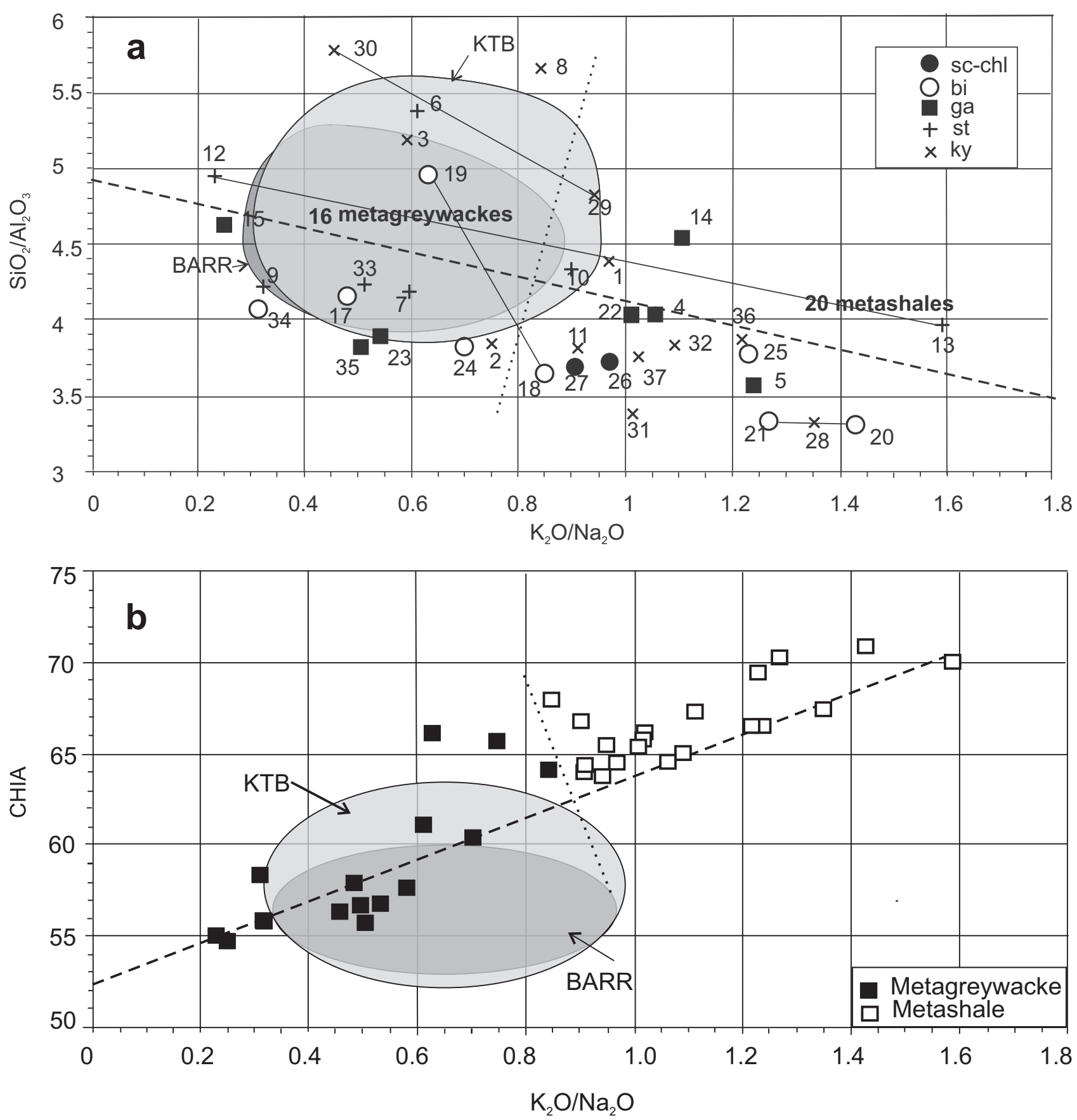

Fig. 2a - Metasedimentary rocks of the TCC in the plot of Wimmenauer (1984). Isograd affiliation of samples is: sc-chl - sericite-chlorite, bi biotite, ga - garnet, st - staurolite, ky - kyanite. b - Binary plot $\mathrm{K}_{2} \mathrm{O} / \mathrm{Na}_{2} \mathrm{O}$ vs. CHIA (chemical index of alteration - Nesbit and Young 1982). The grey fields BARR - Barrandian Neoproterozoic, KTB - Superdeep borehole Windisch-Eschenbach/FRG. The dotted line - estimated boundary between metagreywacke and metashale type samples. The dashed line - regression line of all samples. Solid lines connect metagreywacke and metashale pairs from one locality.

for the SRM $987 \mathrm{Sr}$ standard. Procedural blanks were less than $0.1 \%$ of the relevant sample concentrations and are therefore negligible. Uncertainties $( \pm 2 \sigma)$ were $0.03 \%$ for ${ }^{87} \mathrm{Sr} /{ }^{86} \mathrm{Sr}, 0.06 \%$ for ${ }^{143} \mathrm{Nd}^{144} \mathrm{Nd}, 1 \%$ for ${ }^{87} \mathrm{Rb}{ }^{86} \mathrm{Sr}$ and $0.4 \%$ for ${ }^{147} \mathrm{Sm} /{ }^{144} \mathrm{Nd}$ according to long-term measurements of the granite SARM and feldspar NBS 607 standards. Calculation of the $\varepsilon_{\mathrm{Nd}}$ values is based on ${ }^{143} \mathrm{Nd} /{ }^{144} \mathrm{Nd}=0.512638$ and ${ }^{147} \mathrm{Sm} /{ }^{144} \mathrm{Nd}=0.1967$ for a CHUR (Jacobsen and Wasserburg 1980). Single-stage depleted-mantle model ages $\mathrm{T}_{\mathrm{Nd}}(\mathrm{DM})$ were calculated assuming ${ }^{143} \mathrm{Nd} /{ }^{144} \mathrm{Nd}=0.513151$ and ${ }^{147} \mathrm{Sm}^{1 / 44} \mathrm{Nd}=0.219$ for the present-day depleted-mantle reservoir and a linear $\mathrm{Sm} / \mathrm{Nd}$ evolution trough time. In all calculations, the IUGS-recommended constants (Steiger and Jäger 1977) were used. 

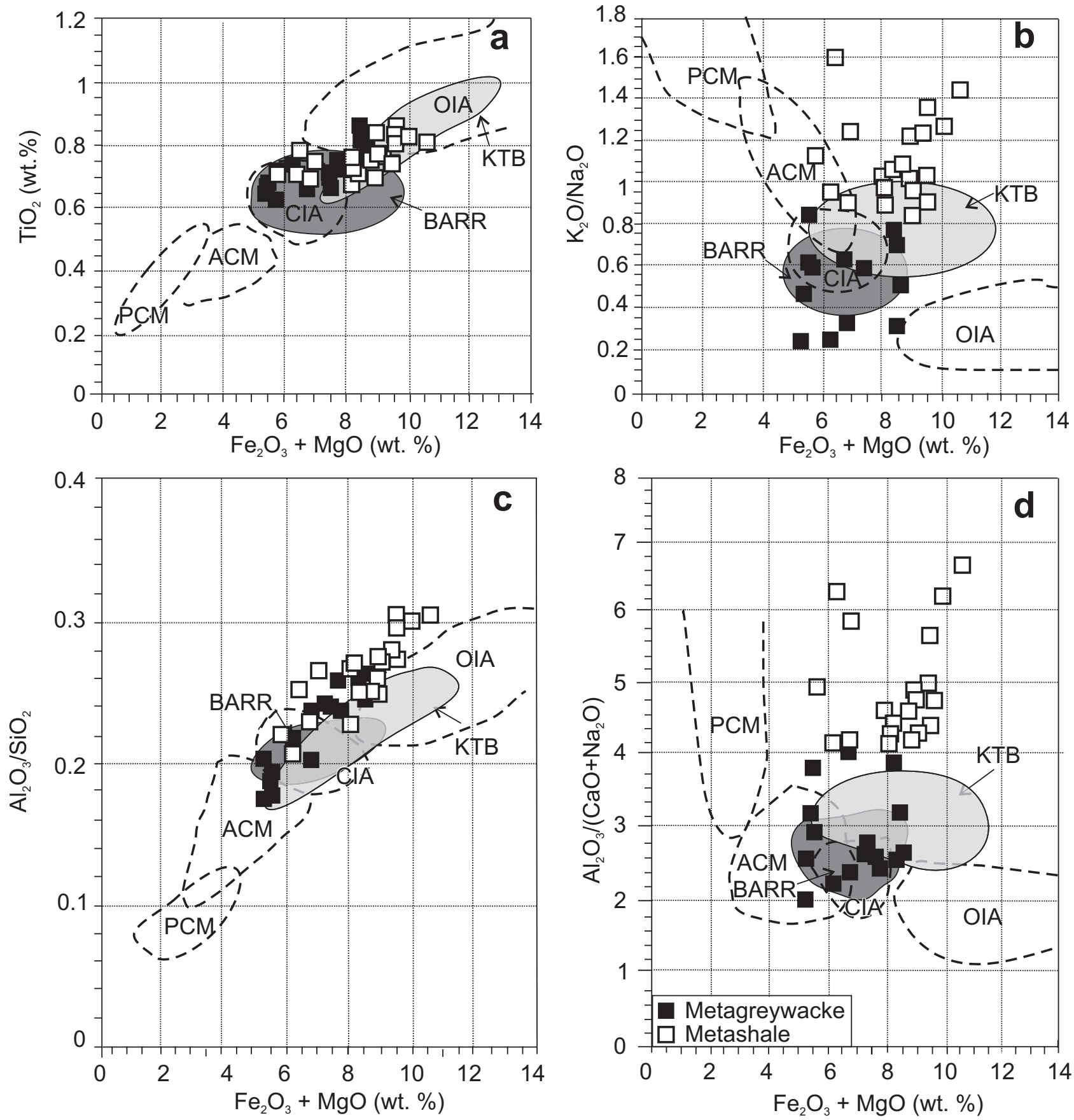

Fig. 3 Metasedimentary rocks of the TCC in the plots of Bhatia (1983). Geotectonic settings: PCM - passive continental margin, ACM - active continental margin, CIA - continental island arc, OIA - oceanic island arc.

\section{Geochemistry}

\subsection{Major elements}

The analysed metasedimentary rocks of the TCC (Tab. 2) contain 60.1 to 73.6 wt. $\% \mathrm{SiO}_{2}$ and 13.0 to 18.7 wt. \% $\mathrm{Al}_{2} \mathrm{O}_{3}$. According to $\mathrm{K}_{2} \mathrm{O} / \mathrm{Na}_{2} \mathrm{O}$ vs. $\mathrm{SiO}_{2} / \mathrm{Al}_{2} \mathrm{O}_{3}$ (all in wt.\%) classification plot of Wimmenauer (1984) (Fig. 2a), almost all the TCC samples plot in the field of grey- wackes. The $\mathrm{K}_{2} \mathrm{O} / \mathrm{Na}_{2} \mathrm{O}$ ratio varies broadly around the median value of 0.8 from about 0.2 to 1.6 , which, at the same time, represents the scatter of the greywacke-shale counterparts from a single locality (samples 12 and 13).

Individual samples in Fig. 2a display a negative trend marked by the regression line (dashed), reflecting progressive weathering and decomposition of mostly plagioclase, connected with an increase in clay mineral proportion in the primary sediment. Empirical line 


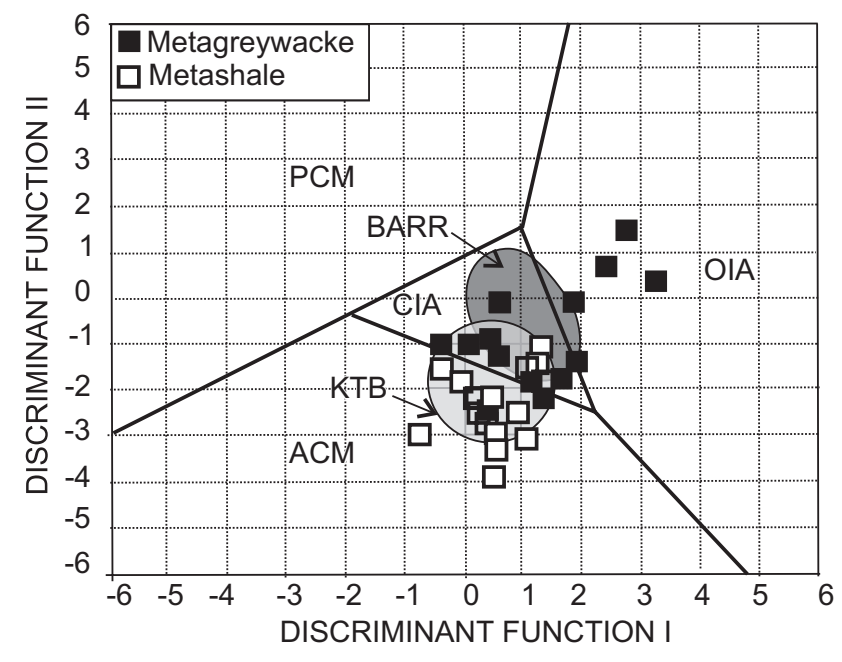

Fig. 4 Metasedimentary rocks of the TCC in the plot of discriminants scores after Bhatia (1983). For abbreviations see Fig. 3.

(dotted) in Fig. 2a separates 16 metagreywackes from 20 metashales based on field evidence. We use this division also in further projections.

No systematic compositional changes are observed from the lowest to the highest grades of metamorphism or across the strike of the isograds (Fig. 1). Variations due to sedimentary sorting within a sedimentary succession (marked sample pairs in Fig. 2a) exceed that between samples of different metamorphic grades or geographic positions.

Geochemical relationship between the TCC and the unmetamorphosed to anchimetamorphosed Barrandian Neoproterozoic metasedimentary rocks was assessed using data of Čadková et al. (1985). We prefer this geochemical database produced in a single laboratory of the Czech Geological Survey. The field "BARR" in Fig. 2a covers $90 \%$ of data points of 50 Barrandian greywacke samples. Geochemical relation of the TCC to the similar metamorphosed monotonous sequence of the western part of the Bohemian Massif, the Erbendorf-Vohenstrauß Zone, was studied using data of Wimmenauer (1991). The field "KTB" in Fig. 2a covers $90 \%$ of data points of 40 metagreywacke samples from the KTB superdeep borehole.

The plot of $\mathrm{K}_{2} \mathrm{O} / \mathrm{Na}_{2} \mathrm{O}$ (in wt. \%) vs. the chemical index of alteration (CHIA according to Nesbitt and Young 1982) is shown in Fig. 2b. The CHIA is defined as the molar ratio $\mathrm{Al}_{2} \mathrm{O}_{3} /\left(\mathrm{Al}_{2} \mathrm{O}_{3}+\mathrm{K}_{2} \mathrm{O}+\mathrm{Na}_{2} \mathrm{O}+\mathrm{CaO} *\right) \times 100$, where $\mathrm{CaO}^{*}$ represents $\mathrm{Ca}$ residing only in silicate minerals (i.e., corrected for $\mathrm{Ca}$ in carbonates and phosphates). The TCC samples exhibit a positive trend marked by a regression line (dashed) reflecting a more intense alteration of metashale samples. The CHIA cut-off value of about 63 separates most of metagreywackes (down to 54.7) from metashales (up to 70.8). Note that the Barrandian and KTB fields (see Fig. 2a) plot within the "metagrey- wacke" domain, i.e. that characterized by relatively low degree of alteration.

Major-element compositions of clastic sediments show systematic variations depending on the tectonic setting (Bhatia 1983). Figure 3 plots mafic components of $\mathrm{Fe}_{2} \mathrm{O}_{3}$ (total iron) $+\mathrm{MgO}$ in wt. \% against $\mathrm{TiO}_{2}$ (wt. $\%), \mathrm{K}_{2} \mathrm{O} / \mathrm{Na}_{2} \mathrm{O}, \mathrm{Al}_{2} \mathrm{O}_{3} / \mathrm{SiO}_{2}$ and $\mathrm{Al}_{2} \mathrm{O}_{3} /\left(\mathrm{CaO}+\mathrm{Na}_{2} \mathrm{O}\right)$, respectively. Possible tectonic settings are as follows: passive continental margin (PCM), active continental margin (ACM), continental-island arc (CIA) and oceanicisland arc (OIA). In Fig. 3a, the studied metagreywackes plot mostly to the CIA field, whereas metashales shift slightly to the OIA field. The latter is probably due to relative mafic component enrichment in the clayey phase of the primarily more altered shale variety. The Barrandian greywackes cover the CIA field whereas the KTB ones straddle the boundary of the adjacent OIA field. Figures $3 \mathrm{~b}$, d document a conspicuous mobility of alkalis and $\mathrm{CaO}$ due to weathering and decomposition processes. In both cases, the less altered greywackes plot in the CIA field, whereas in Fig. 3b, the more strongly altered shales fall outside any of the fields defined. In the above-mentioned figures, the KTB metagreywacke data shift markedly in the same sense as the TCC metashales. Plots with less mobile elements (Fig. 3a, c) produce more compact pictures, which holds particularly for the Barrandian greywackes probably spared of stronger alteration.

Taken together, the set of major-element plots in Fig. 3 suggest a mostly CIA provenance for the studied samples, as well as for the KTB and BARR greywacke sediments. The same conclusion comes from the plot of major-element based discriminant functions after Bhatia (1983) (Fig. 4). All the presented plots were set up by analysing "sandstones", in fact mostly by greywackes in island-arc settings (Bhatia 1983). For chemically more altered shale lithologies, the discrimination diagrams are more or less invalid.

\subsection{Binary and ternary plots based on trace elements}

Trace-element data of the analysed TCC metasediments are given in Tab. 3. Various plots are used to discriminate the provenance of the sedimentary protolith (Figs 5-6). In the ternary $\mathrm{Co}-\mathrm{Th}-\mathrm{Zr} / 10$ plot of Bhatia and Crook (1986) (Fig. 5a), the TCC metasediments and Barrandian greywackes concentrate in the continental-island arc area (in the KTB data set, Co analyses are missing). The Sc$\mathrm{Th}-\mathrm{Zr} / 10$ plot (Fig. 5b) provides a similar picture. The KTB field is also missing, because of the lack of Sc data. The La vs. Th plot (Fig. 6a) points unequivocally to a CIA setting only for the Barrandian greywackes, whereas the TCC and KTB metasediment data fall mostly outside the delimited fields. The "normal" $\mathrm{La} / \mathrm{Th}$ ratio of the 
Tab. 3 Trace-element data (except REE) for the Teplá Crystalline Complex metasediments [ppm]

\begin{tabular}{|c|c|c|c|c|c|c|c|c|c|c|c|c|c|c|c|c|c|c|}
\hline No. & 1 & 2 & 3 & 4 & 5 & 6 & 7 & 8 & 9 & 10 & 11 & 12 & 13 & 14 & 15 & 17 & 18 & 19 \\
\hline $\mathrm{Rb}$ & 86 & 68 & 83 & 96 & 95 & 61 & 65 & 68 & 68 & 87 & 96 & 50 & 98 & 81 & 41 & 66 & 89 & 64 \\
\hline $\mathrm{Sr}$ & 22 & 190 & 145 & 135 & 131 & 157 & 231 & 127 & 204 & 128 & 148 & 170 & 110 & 84 & 135 & 223 & 120 & 122 \\
\hline $\mathrm{a}$ & 74 & 713 & 465 & 620 & 572 & 486 & 387 & 505 & 246 & 533 & 527 & 167 & 723 & 675 & 432 & 420 & 554 & 535 \\
\hline b & 14 & 17 & 14 & 21 & 24 & 12 & 12 & 16 & 27 & 20 & 19 & 13 & 15 & 16 & 17 & 19 & 17 & 14 \\
\hline $\mathrm{u}$ & 29 & 27 & 8 & 28 & 36 & 5 & 18 & 12 & 4 & 12 & 22 & 19 & 20 & 18 & 3 & 23 & 25 & 18 \\
\hline n & 07 & 100 & 81 & 99 & 124 & 67 & 61 & 56 & 78 & 82 & 89 & 104 & 85 & 67 & 33 & 77 & 107 & 77 \\
\hline a & 17 & 19 & 13 & 18 & 20 & 13 & 17 & 12 & 13 & 17 & 20 & 11 & 19 & 17 & 12 & 15 & 18 & 14 \\
\hline $\mathrm{Jb}$ & 9 & 10 & 8 & 9 & 10 & 7 & 3 & 7 & 8 & 8 & 10 & 7 & 10 & 8 & 7 & 5 & 11 & 7 \\
\hline $\mathrm{Zr}$ & 74 & 261 & 265 & 176 & 171 & 250 & 145 & 217 & 216 & 217 & 193 & 229 & 198 & 210 & 213 & 188 & 197 & 199 \\
\hline If & 6 & 6 & 7 & 5 & 5 & 5 & 4 & 6 & 6 & 6 & 7 & 6 & 5 & 5 & 6 & 5 & 4 & 5 \\
\hline $\mathrm{h}$ & 7.7 & 13.8 & 8.4 & 8.2 & 8.1 & 8.0 & 5.1 & 6.5 & 8.6 & 8.2 & 9.2 & 7.6 & 8.4 & 7.7 & 7.9 & 6.4 & 8.7 & 7.2 \\
\hline & 3.2 & 3.1 & 3.3 & 3.1 & 2.9 & 2.7 & 1.4 & 2.6 & 3.1 & 3.1 & 3.3 & 3.0 & 3.9 & 3.1 & 3.1 & 2.1 & 1.7 & 1.8 \\
\hline & 30 & 55 & 28 & 32 & 30 & 26 & 23 & 26 & 29 & 30 & 30 & 29 & 33 & 31 & 33 & 24 & 29 & 23 \\
\hline ic & 13 & 14 & 12 & 16 & 16 & 13 & 15 & 13 & 15 & 15 & 15 & 16 & 15 & 15 & 12 & 14 & 14 & 14 \\
\hline & 147 & 154 & 111 & 164 & 165 & 106 & 114 & 106 & 124 & 133 & 144 & 101 & 174 & 146 & 141 & 114 & 163 & 129 \\
\hline $\mathrm{Cr}$ & 81 & 70 & 58 & 89 & 88 & 68 & 78 & 64 & 63 & 62 & 78 & 46 & 76 & 58 & 66 & 49 & 85 & 66 \\
\hline Co & 20 & 11 & 5 & 7 & 16 & 4 & 13 & 4 & 12 & 10 & 13 & 11 & 3 & 3 & 9 & 12 & 16 & 11 \\
\hline $\mathrm{Ni}$ & 45 & 14 & 13 & 25 & 38 & 15 & 26 & 14 & 24 & 25 & 31 & 48 & 6 & 5 & 21 & 18 & 36 & 27 \\
\hline $\mathrm{a}$ & 37.9 & 57.9 & 33.8 & 36.5 & 34.1 & 31.3 & 26.6 & 30.6 & 31.0 & 31.8 & 35.6 & 30.8 & 37.0 & 31.9 & 33.0 & 28.5 & 16.1 & 11.1 \\
\hline $\mathrm{Th} / \mathrm{Sc}$ & 0.59 & 0.99 & 0.70 & 0.51 & 0.51 & 0.62 & 0.34 & 0.50 & 0.57 & 0.54 & 0.61 & 0.48 & 0.56 & 0.51 & 0.66 & 0.46 & 0.62 & 0.52 \\
\hline $\mathrm{r} / \mathrm{Sc}$ & 13.4 & 18.6 & 22.1 & 11.0 & 10.7 & 19.2 & 9.7 & 16.7 & 14.4 & 14.5 & 12.9 & 14.3 & 13.2 & 14.0 & 17.8 & 13.4 & 14.1 & 14.2 \\
\hline $\mathrm{Th} / \mathrm{U}$ & 2.40 & 4.40 & 2.52 & 2.66 & 2.82 & 2.96 & 3.57 & 2.49 & 2.76 & 2.68 & 2.79 & 2.56 & 2.19 & 2.50 & 2.55 & 3.11 & 4.98 & 4.09 \\
\hline $\mathrm{Cr} / \mathrm{V}$ & 0.55 & 0.45 & 0.52 & 0.54 & 0.53 & 0.64 & 0.68 & 0.60 & 0.51 & 0.47 & 0.54 & 0.46 & 0.44 & 0.40 & 0.47 & 0.43 & 0.52 & 0.51 \\
\hline $\mathrm{Y} / \mathrm{Ni}$ & 0.66 & 3.90 & 2.16 & 1.28 & 0.80 & 1.71 & 0.89 & 1.83 & 1.21 & 1.19 & 0.97 & 0.60 & 5.49 & 6.17 & 1.56 & 1.33 & 0.81 & 0.8 \\
\hline $\mathrm{a} / \mathrm{Sc}$ & 2.91 & 4.13 & 2.81 & 2.28 & 2.13 & 2.41 & 1.77 & 2.35 & 2.07 & 2.12 & 2.38 & 1.92 & 2.46 & 2.13 & 2.75 & 2.03 & 1.15 & 0.8 \\
\hline $\mathrm{R} / \mathrm{Sr}$ & 0.70 & 0.36 & 0.57 & 0.71 & 0.73 & 0.39 & 0.28 & 0.54 & 0.33 & 0.68 & 0.65 & 0.29 & 0.89 & 0.96 & 0.30 & 0.30 & 0.74 & 0.5 \\
\hline $\mathrm{r} / \mathrm{Ni}$ & 1.80 & 5.00 & 4.46 & 3.56 & 2.32 & 4.53 & 3.00 & 4.57 & 2.63 & 2.48 & 2.52 & 0.96 & 12.67 & 11.60 & 3.14 & 2.72 & 2.36 & 2.4 \\
\hline No. & 20 & 21 & 22 & 23 & 24 & 25 & 26 & 27 & 28 & 29 & 30 & 31 & 32 & 33 & 34 & 35 & 36 & 37 \\
\hline $\mathrm{kb}$ & 10 & 104 & 91 & 67 & 78 & 108 & 96 & 93 & 122 & 78 & 55 & & 99 & 69 & 51 & 69 & 94 & 103 \\
\hline $\mathrm{Sr}$ & 95 & 99 & 146 & 305 & 203 & 115 & 121 & 89 & 125 & 140 & 177 & 150 & 123 & 297 & 252 & 289 & 132 & 123 \\
\hline $3 a$ & 730 & 697 & 602 & 495 & 611 & 665 & 596 & 598 & 625 & 560 & 404 & 565 & 518 & 460 & 623 & 480 & 593 & 525 \\
\hline $\mathrm{Pb}$ & 18 & 19 & 26 & 26 & 24 & 31 & 26 & 15 & 18 & 22 & 22 & 26 & 24 & 19 & 12 & 14 & 13 & 22 \\
\hline $\mathrm{Cu}$ & 2 & 2 & 19 & 10 & 12 & 18 & 31 & 30 & 2 & 1 & 10 & 21 & 3 & 8 & 14 & 18 & 0 & 8 \\
\hline $\mathrm{Zn}$ & 125 & 114 & 109 & 82 & 92 & 101 & 107 & 112 & 118 & 87 & 69 & 109 & 104 & 79 & 77 & 100 & 123 & 109 \\
\hline $\mathrm{Ga}$ & 22 & 22 & 18 & 16 & 19 & 19 & 19 & 20 & 23 & 16 & 11 & 20 & 20 & 18 & 15 & 19 & 20 & 20 \\
\hline $\mathrm{Nb}$ & 11 & 11 & 10 & 6 & 10 & 9 & 11 & 11 & 14 & 8 & 7 & 12 & 10 & 8 & 6 & 11 & 12 & 11 \\
\hline & 176 & 183 & 171 & 179 & 227 & 220 & 198 & 195 & 206 & 226 & 249 & 194 & 177 & 211 & 221 & 203 & 224 & 207 \\
\hline $\mathrm{Hf}$ & 4 & 5 & 5 & 5 & 6 & 6 & 6 & 6 & 5 & 6 & 7 & 5 & 4 & 6 & 6 & 5 & 6 & 6 \\
\hline Th & 9.0 & 9.3 & 8.5 & 5.7 & 8.5 & 8.5 & 9.5 & 9.3 & 10.2 & 7.9 & 8.0 & 9.4 & 8.4 & 7.2 & 7.3 & 9.3 & 8.7 & 9.6 \\
\hline U & 2.0 & 1.9 & 2.7 & 1.7 & 2.2 & 2.8 & 3.0 & 2.8 & 3.8 & 3.2 & 2.7 & 3.7 & 3.2 & 2.4 & 2.2 & 2.0 & 3.8 & 3.6 \\
\hline & 25 & 25 & 25 & 16 & 29 & 21 & 25 & 31 & 32 & 29 & 23 & 34 & 31 & 25 & 24 & 22 & 34 & 34 \\
\hline $\mathrm{Sc}$ & 16 & 11 & 13 & 15 & 13 & 14 & 14 & 13 & 16 & 16 & 14 & 12 & 17 & 13 & 14 & 15 & 14 & 14 \\
\hline & 188 & 196 & 158 & 135 & 131 & 150 & 176 & 180 & 185 & 128 & 110 & 172 & 159 & 126 & 142 & 174 & 168 & 161 \\
\hline $\mathrm{Cr}$ & 99 & 100 & 81 & 74 & 67 & 63 & 94 & 84 & 91 & 84 & 70 & 104 & 78 & 65 & 66 & 92 & 75 & 90 \\
\hline & & 11 & 16 & 9 & 11 & 8 & 11 & 18 & 14 & 8 & 6 & 14 & 13 & 13 & 15 & 16 & 16 & 12 \\
\hline $\mathrm{Ni}$ & 47 & 45 & 39 & 11 & 23 & 15 & 42 & 44 & 34 & 26 & 16 & 29 & 35 & 20 & 20 & 42 & 37 & 28 \\
\hline $\mathrm{La}$ & 16.9 & 11.6 & 33.2 & 9.3 & 36.4 & 26.4 & 34.0 & 36.3 & 36.8 & 33.2 & 31.7 & 40.6 & 34.2 & 26.2 & 27.2 & 16.5 & 36.8 & 35.2 \\
\hline $\mathrm{Th} / \mathrm{S}$ & 0.56 & 0.85 & 0.66 & 0.38 & 0.65 & 0.60 & 0.68 & 0.72 & 0.64 & 0.50 & 0.57 & 0.78 & $\begin{array}{ll}3 & 0.49\end{array}$ & 0.55 & 0.52 & 0.62 & 0.62 & 0.68 \\
\hline $\mathrm{r} / \mathrm{Sc}$ & 11.0 & 16.6 & 13.2 & 11.9 & 17.5 & 15.7 & 14.1 & 15.0 & 12.9 & 14.1 & 17.8 & 16.2 & 10.4 & 16.2 & 15.8 & 13.5 & 16.0 & 14.8 \\
\hline $\mathrm{Th} / \mathrm{U}$ & 4.47 & 4.89 & 3.18 & 3.35 & 3.92 & 3.04 & 3.16 & 3.34 & 2.68 & 2.44 & 2.95 & 2.53 & 2.65 & 2.93 & 3.27 & 4.61 & 2.29 & 2.69 \\
\hline $\mathrm{r} / \mathrm{V}$ & & 0.51 & 0.51 & 0.55 & 0.51 & 0.42 & 0.53 & 0.47 & 0.49 & 0.66 & 0.64 & 0.60 & 0.49 & 0.52 & 0.46 & 0.53 & 0.45 & 0.5 \\
\hline $\mathrm{Y} / \mathrm{Ni}$ & 0.54 & 0.56 & 0.63 & 1.44 & 1.27 & 1.39 & 0.60 & 0.70 & 0.95 & 1.11 & 1.43 & 1.18 & 0.89 & 1.23 & 1.22 & 0.53 & 0.91 & 1.2 \\
\hline $\mathrm{a} / \mathrm{Sc}$ & 1.05 & 1.05 & 2.56 & 0.62 & 2.80 & 1.89 & 2.43 & 2.79 & 2.30 & 2.07 & 2.27 & 3.38 & 2.01 & 2.01 & 1.94 & 1.10 & 2.63 & 2.51 \\
\hline $\mathrm{Rb} / \mathrm{Sr}$ & 1.16 & 1.05 & 0.62 & 0.22 & 0.38 & 0.94 & 0.79 & 1.04 & 0.98 & 0.56 & 0.31 & 0.71 & 0.80 & 0.23 & 0.20 & 0.24 & 0.71 & 0.84 \\
\hline $\mathrm{Cr} / \mathrm{Ni}$ & 2.11 & 2.22 & 2.08 & 6.73 & 2.91 & 4.20 & 2.24 & 1.91 & 2.68 & 3.23 & 4.38 & 3.59 & 2.23 & 3.25 & 3.30 & 2.19 & 2.03 & 3.21 \\
\hline
\end{tabular}



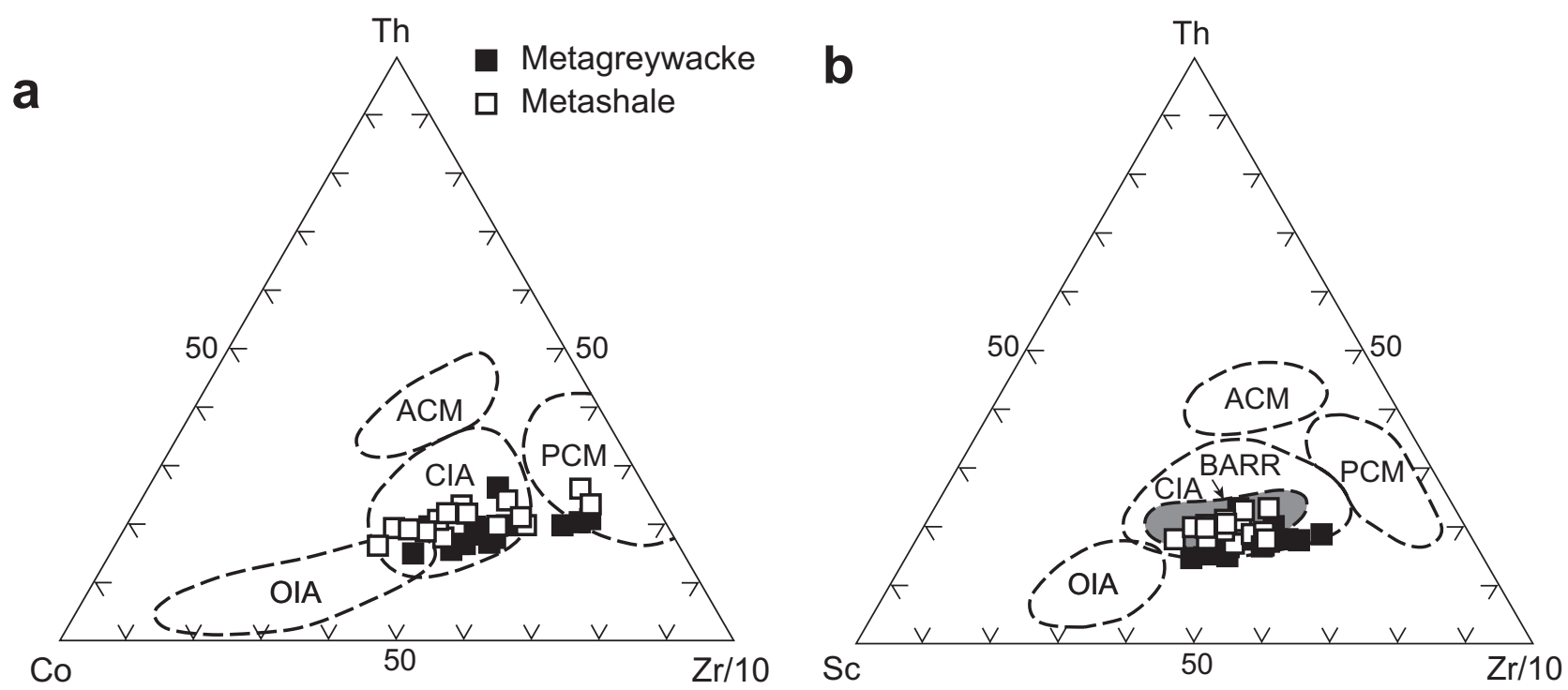

Fig. 5 Metasedimentary rocks of the TCC in the ternary plots of Bhatia and Crook (1986). For the meaning of abbreviations, see Fig 3.

pre-defined fields is $\sim 2$ whereas the majority of TCC and $\mathrm{KTB}$ data concentrate at $\mathrm{La} / \mathrm{Th} \sim 4$. The $\mathrm{La} / \mathrm{Sc}$ vs. Ti/Zr plot of Bhatia and Crook (1986) in Fig. 6b shows again a compact picture. Almost all the TCC and Barrandian data concentrate within the CIA field ( $\mathrm{Sc}$ data are missing in the KTB analyses). Another hint on possible sediment
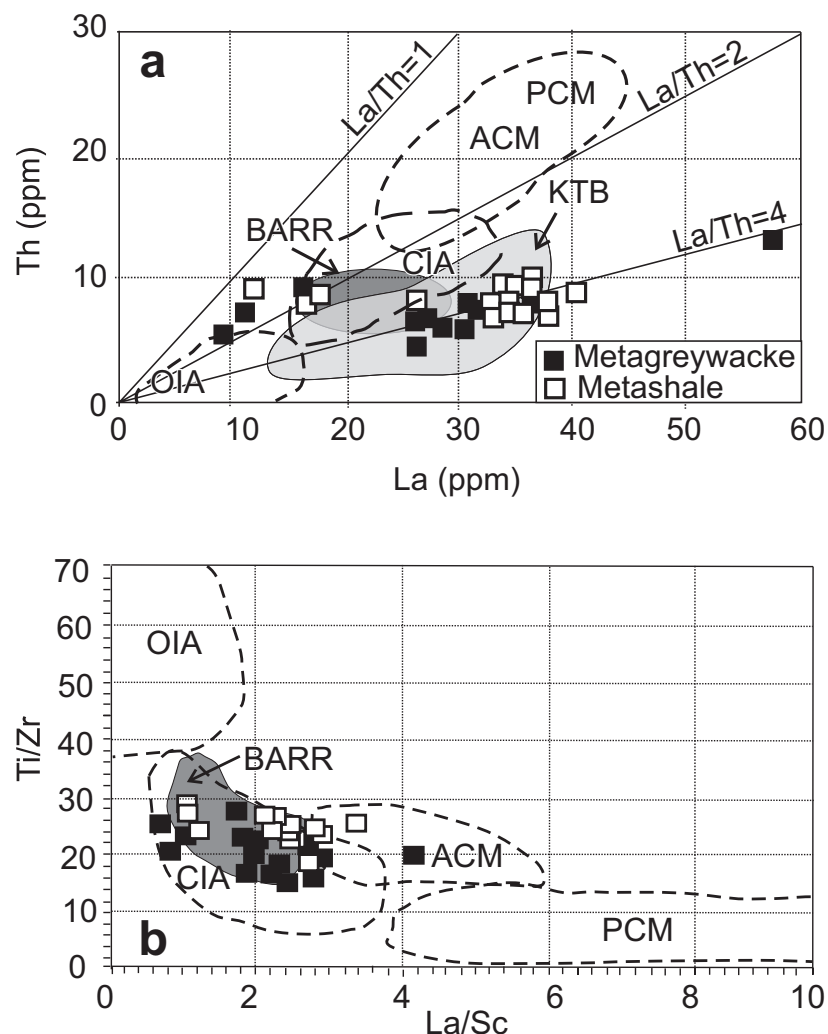

Fig. 6 Metasedimentary rocks of the TCC in the binary plots Bhatia and Crook (1986). a - La vs. Th; $\mathbf{b}-\mathrm{La} / \mathrm{Sc}$ vs. Ti/Zr. For the meaning of abbreviations, see Fig 3. provenance is presented by the Hf vs. La/Th plot of Floyd and Leveridge (1987) (Fig. 7). The so-called "acidic arc source" in this plot corresponds roughly to the CIA area in the previous plots, and the affinity of the TCC, BARR and a part of KTB data to this area is obvious. The remaining KTB data show a tendency to follow the passive margin trend (compare with Fig. 3b, d).

\subsection{Multi-element (spider) diagrams}

Figure 8 is a multi-element plot normalized to Primitive Mantle (PRM) composition after Taylor and McLennan (1985). The element order in the diagram follows the decreasing average contents in the upper continental crust (UCC) according to Taylor and McLennan (1985), except for phosphorus, which is taken from Wänke et al. (1984).

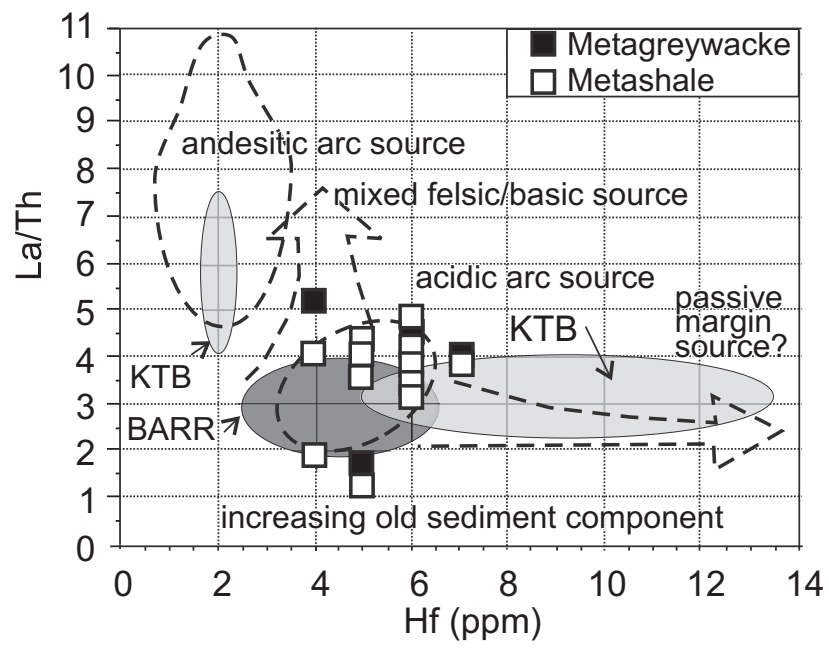

Fig. 7 Metasedimentary rocks of the TCC in the Hf vs. La/Th plot of Floyd and Leveridge (1987). 


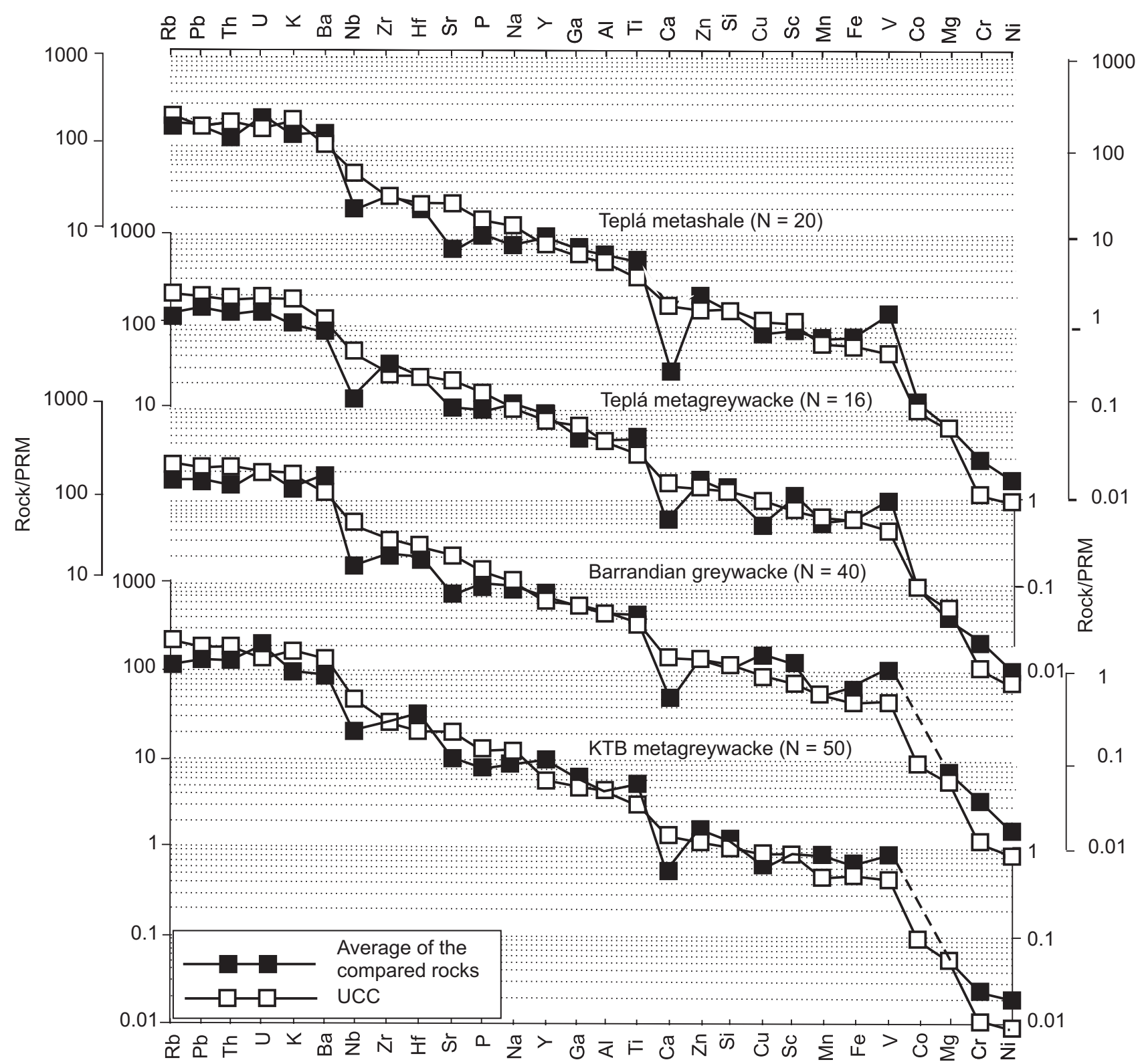

Fig. 8 Multi-element (spider) diagrams of metasedimentary rocks from the Teplá Crystalline Complex and from comparable rocks, all PRM (Primitive Mantle) normalized. Normalization values from Taylor and McLennan (1985). Average Upper Continental Crust (UCC) composition is from Taylor and McLennan (1985) and Wänke et al. (1984).

The PRM-normalized UCC element contents were used as a reference basis for the individual plots.

The TCC data were plotted separately for metashales and metagreywackes to decipher the possible compositional changes due to progressive mechanical and chemical alteration prior to deposition (Fig. 8).

\subsection{Rare earth elements (REE)}

The REE data of the analysed TCC metasediments are presented in Tab. 4. Chondrite-normalized (Taylor and McLennan 1985) REE patterns can be divided into three groups. The most common pattern ( 27 samples) is shown in Fig. 9. This UCC-like distribution is characterized by a steeper course of the LREE, a pronounced negative Eu anomaly $\left(\mathrm{Eu} / \mathrm{Eu}^{*}=0.55-0.79\right)$ and a rather flat HREE segment. The contents of REE are slightly enhanced relative to the UCC distribution, which holds namely for the HREE. The exception to this overall trend is sample No. 2, wherein the REE content is substantially higher.

Figure 10 presents a less common REE pattern of three TCC samples almost lacking the Eu anomaly, in two cases with a smooth, moderately concave course of distribution. The TCC distribution curves in Fig. 10 are well comparable with those of undifferentiated CIA andesites. 
Tab. 4 Rare-earth-element data for the Teplá Crystalline Complex metasediments [ppm]

\begin{tabular}{|c|c|c|c|c|c|c|c|c|c|c|c|c|c|c|c|c|c|c|}
\hline No. & 1 & 2 & 3 & 4 & 5 & 6 & 7 & 8 & 9 & 10 & 11 & 12 & 13 & 14 & 15 & 17 & 18 & 19 \\
\hline $\mathrm{La}$ & 7.9 & 57.9 & 33.8 & 36.5 & 34.1 & 31.3 & 26.6 & 30.6 & 31.0 & 31.8 & 35.6 & 30.8 & 37.0 & 31.9 & 33.0 & 28.5 & 16.1 & 11.1 \\
\hline $\mathrm{Ce}$ & 7.7 & 119.2 & 75.5 & 73.8 & 103.7 & 61.6 & 53.3 & 70.1 & 75.6 & 71.6 & 70.6 & 67.0 & 77.0 & 76.7 & 73.0 & 57.8 & 58.9 & 50.6 \\
\hline $\operatorname{Pr}$ & 8.7 & 14.6 & 7.5 & 9.4 & 7.4 & 6.5 & 5.8 & 6.4 & 7.9 & 7.7 & 7.0 & 8.3 & 8.7 & 8.1 & 8.3 & 7.6 & 4.4 & 2.5 \\
\hline $\mathrm{Nd}$ & 33.0 & 54.7 & 31.6 & 31.6 & 31.4 & 27.7 & 25.3 & 28.5 & 28.7 & 30.4 & 33.5 & 30.5 & 34.7 & 31.5 & 31.6 & 25.6 & 14.7 & 11.1 \\
\hline $\mathrm{Sm}$ & 5.9 & 11.9 & 6.2 & 6.3 & 6.3 & 6.2 & 4.9 & .2 & 5.4 & 6.4 & 7.2 & 3 & 6.6 & 5.9 & 5.8 & 5.1 & 4.0 & 3.0 \\
\hline $\mathrm{Eu}$ & .53 & 2.18 & 1.44 & 1.50 & 1.58 & 1.05 & 1.44 & 1.34 & 1.73 & 1.45 & 1.59 & 1.58 & 1.60 & 1.40 & 1.63 & 0.94 & 0.75 & 0.93 \\
\hline $\mathrm{Gd}$ & 6.7 & 11.9 & & 6.9 & 6.3 & 4.1 & 4.9 & & & 6.0 & 7.1 & & 6.6 & 6.2 & .7 & & 5.2 & 4.4 \\
\hline Dy & 5.4 & 10.6 & 5.8 & 5.9 & 5.7 & 5.6 & 4.3 & 5.1 & 5.7 & 6.0 & 5.9 & 5.7 & 6.2 & 5.8 & 5.9 & 5.7 & 6.3 & 4.5 \\
\hline Но & 1.22 & 1.83 & 0.90 & 1.25 & 0.92 & 1.58 & 0.73 & 0.92 & 1.09 & 0.97 & 0.76 & 0.84 & 1.30 & 1.02 & 1.41 & 2.09 & 2.00 & 0.50 \\
\hline Er & 3.0 & 5.7 & 3.1 & 3.0 & 2.7 & 3.4 & 2.2 & & 3.0 & 2.9 & 3.6 & & 3.0 & 3.0 & 3.3 & 3.6 & 3.8 & 2.8 \\
\hline $\mathrm{Tm}$ & 0.47 & 1.21 & 0.63 & 0.56 & 0.52 & 0.47 & 0.18 & 0.53 & 0.66 & 0.49 & 0.78 & 0.45 & 0.77 & 0.62 & 0.59 & 0.56 & 0.90 & 0.51 \\
\hline $\mathrm{Yb}$ & 3.6 & 6.1 & 1.8 & 3.7 & 3.1 & 3.2 & 2.6 & 2.4 & 3.1 & 3.1 & 3.6 & 2.8 & 4.1 & 3.8 & 3.7 & 2.4 & 3.7 & 3.6 \\
\hline $\mathrm{Lu}$ & 0.49 & 0.84 & 0.18 & 0.51 & 0.41 & 0.72 & 0.39 & 0.28 & 0.39 & 0.38 & 0.47 & 0.35 & 0.59 & 0.49 & 0.53 & 0.82 & 0.87 & 0.44 \\
\hline $\mathrm{Eu} / \mathrm{Eu}^{*}$ & 0.74 & 0.55 & 0.74 & 0.69 & 0.76 & 0.60 & 0.89 & 0.77 & 0.96 & 0.71 & 0.67 & 0.79 & 0.73 & 0.71 & 0.79 & 0.55 & 0.50 & 0.79 \\
\hline $\mathrm{Ce} / \mathrm{Ce}^{*}$ & 0.98 & 0.94 & 1.08 & 0.92 & 1.48 & 0.97 & 0.97 & 1.13 & 1.11 & 1.05 & 0.99 & 0.97 & 0.98 & 1.10 & 1.01 & 0.91 & 1.62 & 2.18 \\
\hline
\end{tabular}

\begin{tabular}{|c|c|c|c|c|c|c|c|c|c|c|c|c|c|c|c|c|c|c|}
\hline No. & 20 & 21 & 22 & 23 & 24 & 25 & 26 & 27 & 28 & 29 & 30 & 31 & 32 & 33 & 34 & 35 & 36 & 37 \\
\hline $\mathrm{La}$ & 16.9 & 11.6 & 33.2 & 9.3 & 36.4 & 26.4 & 34.0 & 36.3 & 36.8 & 33.2 & 31.7 & 40.6 & 34.2 & 26.2 & 27.2 & 16.5 & 36.8 & 35.2 \\
\hline $\mathrm{Ce}$ & 50.4 & 31.0 & 67.1 & 22.7 & 70.9 & 58.0 & 70.2 & 70.5 & 73.0 & 67.7 & 63.6 & 76.3 & 72.3 & 54.7 & 58.1 & 51.2 & 74.8 & 72.3 \\
\hline$r$ & 5.1 & 2.6 & 9.7 & & 9.1 & 6.1 & 8.0 & 9.6 & 9.3 & 7.1 & 6.9 & 8.9 & 8.1 & 6.8 & 7.1 & 3.1 & 9.8 & 9.1 \\
\hline $\mathrm{Jd}$ & 14.7 & 10.6 & 30.8 & 10.2 & 34.2 & 25.9 & 30.9 & 33.9 & 35.1 & 33.0 & 26.9 & 37.0 & 33.2 & 26.1 & 28.2 & 16.0 & 37.3 & 35.2 \\
\hline $\mathrm{Sm}$ & 3.6 & 3.2 & 6.2 & 2.3 & 6.6 & 4.2 & 6.6 & 6.6 & 7.8 & 6.1 & 5.2 & 8.5 & 6.6 & 5.6 & 5.4 & 4.0 & 7.2 & 6.7 \\
\hline $\mathrm{u}$ & 0.89 & 0.73 & 1.43 & 0.62 & 1.62 & 1.13 & 1.35 & 1.41 & 1.61 & 1.53 & 1.32 & 1.84 & 1.52 & 1.38 & 1.40 & 1.01 & 1.61 & 1.57 \\
\hline d & & 3.2 & 5.8 & 1.6 & 6.6 & 4.7 & & & 6.7 & & & & 7.5 & & & 3.8 & & 8.1 \\
\hline$y$ & 4.7 & 4.6 & 4.9 & 3.1 & 6.0 & 4.5 & 5.0 & 6.5 & 6.3 & 5.6 & 4.8 & 6.7 & 5.8 & 4.4 & 4.8 & 4.3 & 6.5 & 6.6 \\
\hline o & 0.92 & 0.78 & 0.89 & 1.02 & 0.98 & 0.59 & & 1.32 & 1.19 & & & & 1.24 & & 0.89 & 0.75 & & 1.44 \\
\hline & 3.0 & 2.7 & 2.9 & 3.0 & 3.8 & 2.8 & 3.0 & 4.0 & 3.4 & 3. & 2.9 & 4.3 & 3.4 & 3.0 & 3.1 & 3.1 & 3.8 & 4.2 \\
\hline $\mathrm{Tm}$ & 0.62 & 0.47 & 0.58 & 0.24 & 0.53 & 0.58 & 0.37 & 0.84 & 0.84 & 0.69 & 0.56 & 1.06 & 0.76 & & 0.56 & 0.63 & & 0.72 \\
\hline $\mathrm{Yb}$ & 3.2 & 2.2 & 3.1 & 2.5 & 3.3 & 2.5 & 2.6 & 3.8 & 3.9 & 3.3 & 2.8 & 4.1 & 3.8 & 2.7 & 2.9 & 3.0 & 4.1 & 4.2 \\
\hline $\mathrm{Lu}$ & & 0.25 & 0.39 & 0.53 & 0.40 & 0.27 & 0.32 & 0.56 & 0.52 & 0.44 & 0.43 & 0.55 & 0.51 & & & 0.38 & & 0.58 \\
\hline $\mathrm{Eu} / \mathrm{Eu}^{*}$ & 0.71 & 0.70 & 0.72 & 0.95 & 0.74 & 0.77 & 0.65 & 0.65 & 0.67 & 0.79 & 0.72 & 0.68 & 0.66 & 0.78 & 0.78 & 0.78 & 0.70 & 0.65 \\
\hline $\mathrm{Ce} / \mathrm{Ce} *$ & 1.26 & 1.28 & 0.87 & 0.99 & 0.89 & 1.04 & 0.97 & 0.87 & 0.91 & 1.00 & 0.97 & 0.91 & 0.99 & 0.94 & 0.97 & 1.58 & 0.91 & 0.93 \\
\hline
\end{tabular}

The last REE distribution type is represented by six samples in Fig. 11 which display, besides the negative Eu anomalies, a distinct positive anomaly of $\mathrm{Ce}$; the other LREE are less enriched. These samples from the lower part of the biotite zone (Fig. 1).

\subsection{Sr and Nd isotopic studies}

From the total of 36 samples for the TCC metasedimentary rocks, nine representative samples were selected for $\mathrm{Sr}-\mathrm{Nd}$ isotopic studies. Four samples from anchi- to unmetamorphosed Barrandian sedimentary rocks were also selected for comparison ("K-" samples from the geochemical database of Czech Geological Survey, Čadková et al. 1985). The resulting data are presented in Tab. 5.

The sedimentation age of $550 \mathrm{Ma}$ used for calculation of $\mathrm{Sr}$ initial ratios and epsilon $\mathrm{Nd}$ values is constrained by the existing zircon $\mathrm{U}-\mathrm{Pb}$ data for the Teplá orthogneiss, which are interpreted as dating emplacement of its protolith (Dörr et al. 1995). The application of singleand two-stage evolution models of the $\mathrm{Sm}-\mathrm{Nd}$ system
(DePaolo 1991) yielded two groups of $\mathrm{T}_{\mathrm{DM}}$ model ages. The difference of $\mathrm{T}_{\mathrm{DM}}$ values between the two models is mostly negligible except for samples with a positive $\mathrm{Ce}$ anomaly. The latter yielded generally higher model ages $\left(\mathrm{T}_{\mathrm{DM}}\right.$-single $\left.=1.8-2.0 \mathrm{Ga}\right)$ than the other samples $\left(\mathrm{T}_{\mathrm{DM}}\right.$ $=1.0-1.5 \mathrm{Ga})$. The initial ${ }^{87} \mathrm{Sr} /{ }^{86} \mathrm{Sr}$ ratios for all samples are fairly constant and compatible with the assumption of a dominance of detrital material, that was isotopically less evolved.

Figure 12 represents the ${ }^{87} \mathrm{Sr} /{ }^{86} \mathrm{Sr}(\mathrm{T})$ vs. $\varepsilon_{\mathrm{Nd}}(\mathrm{T})$ plot for the TCC and ZEV (including KTB) metasedimentary rocks. Variation fields of some Saxothuringian and Moldanubian metasediments are given for comparison (Liew and Hofmann 1988; Henjes-Kunst 2000). The KTB data (KTB-VB) come also from von Drach and Köhler (1993). In general, two groups of data are observed: one containing TCC, ZEV, KTB-VB and unmetamorphosed Barrandian (BARR), and another one of Saxothuringian and Moldanubian samples. Plots $\mathrm{La}_{\mathrm{N}} / \mathrm{Yb}_{\mathrm{N}}-\varepsilon_{\mathrm{Nd}}(\mathrm{T})$ and ${ }^{87} \mathrm{Sr} /{ }^{86} \mathrm{Sr}(\mathrm{T})-\varepsilon_{\mathrm{Nd}}(\mathrm{T})$ (Fig. 13) illustrates the $\mathrm{Sr}-\mathrm{Nd}$ isotopic evolution of the Barrandian (meta-) sedimentary rocks in time. 
Fig. 9 Chondrite-normalized (Taylor and McLennan 1985) REE distribution in 27 metasedimentary rocks of the Teplá Crystalline Complex (Nos. 1-4, $6,8,10-15,17,22,24-34,36,37)$. For UCC composition, see Fig. 7.

\section{Discussion}

The multielement distribution curves on the Fig. 8 display several distinct anomalies connected predominantly to the character of the source rocks and the subsequent disintegration and weathering processes. Comparison of sedimentologically primitive greywackes with more mature shales shows mostly an increase in positive anomalies and a decrease in negative anomalies with the increasing maturity of sediments. The only exceptions are negative anomalies of $\mathrm{Ca}$ and $\mathrm{Sr}$, which deepen in more mature sediments. This can be explained by synergy of two processes: mechanical disintegration, which elevated the trace element-rich pelitic component in shales, and progressive chemical decomposition

Fig. 10 Chondrite-normalized (Taylor and McLennan 1985) REE distribution in three metasedimentary rocks of the Teplá Crystalline Complex.

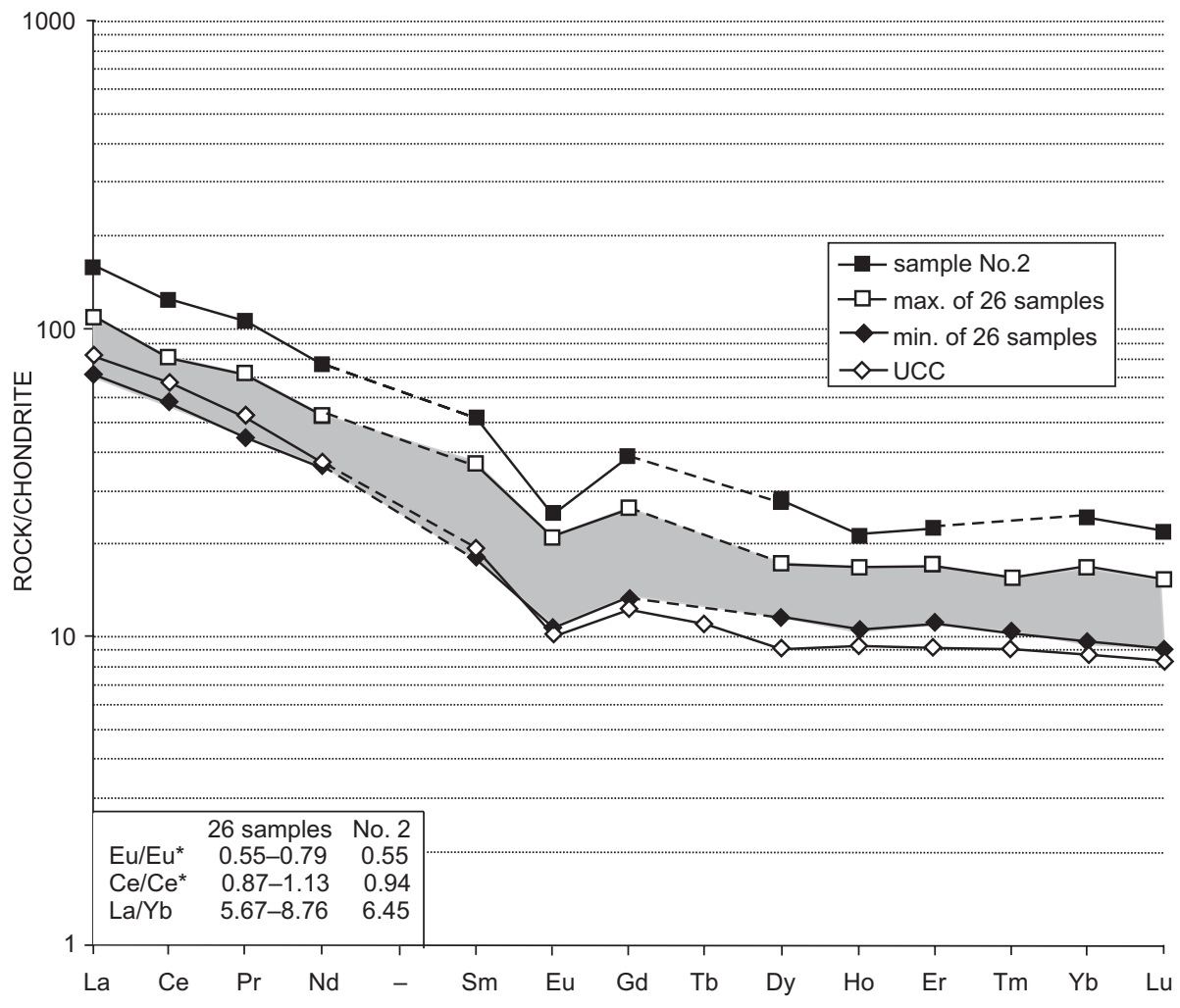

of plagioclase, leading to liberation of part of the $\mathrm{Ca}$ and Sr into seawater.

The differences from the reference UCC curve will be discussed for the TCC metagreywackes because

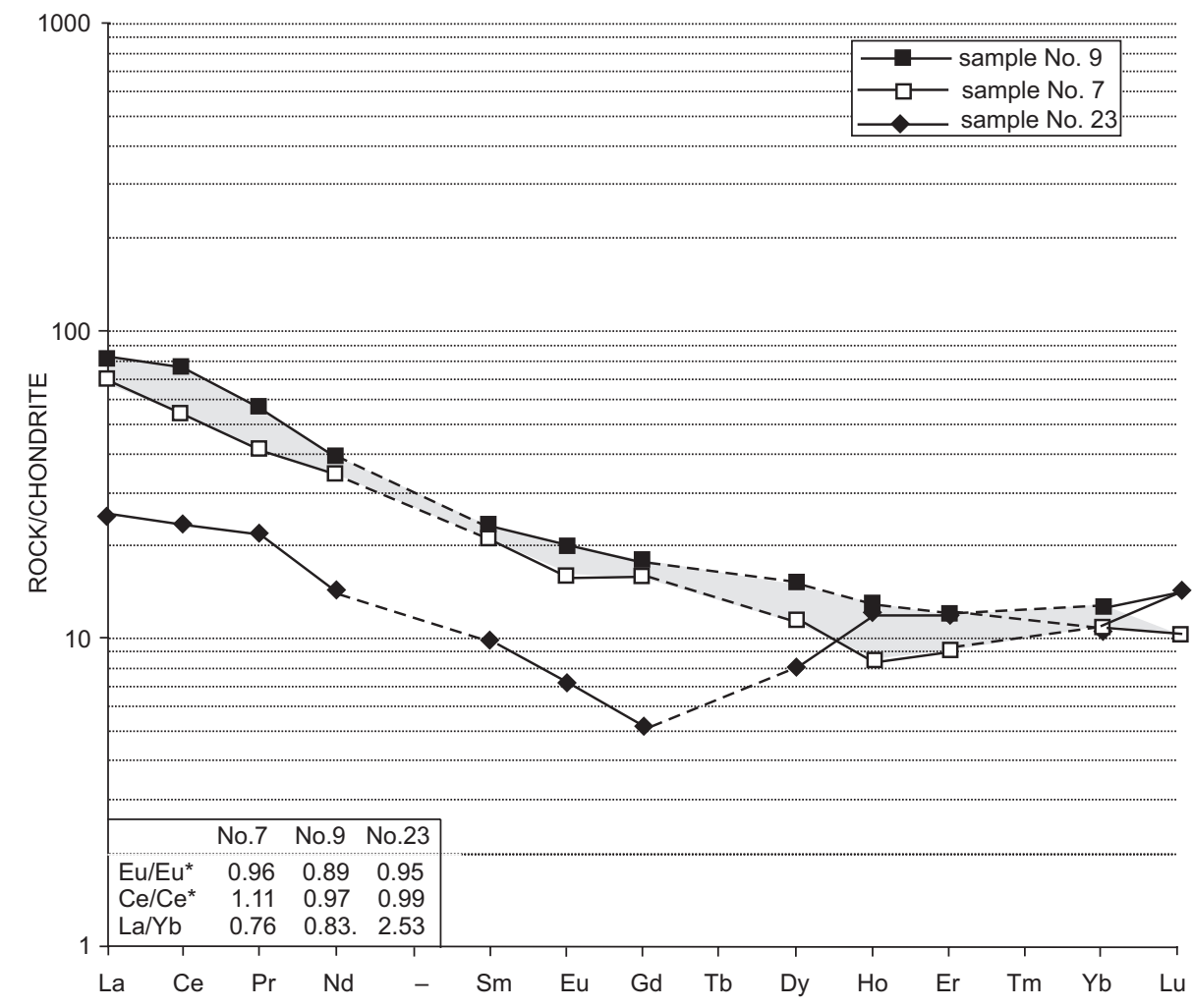




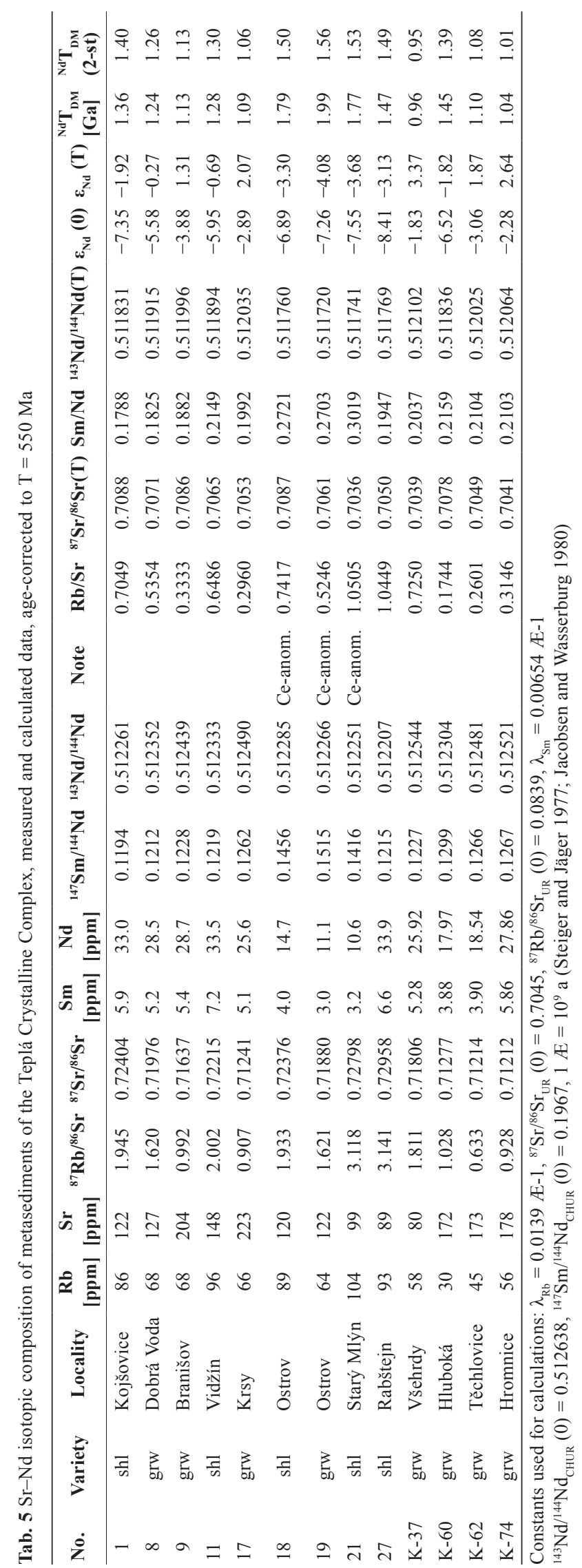

they reflect the primary composition better than the metashales. Large ion lithophile elements (LILE) from $\mathrm{Rb}$ to $\mathrm{Ba}$ in the TCC metagreywackes show a marked depletion relative to UCC, which documents their immature character from the crustal evolution point of view. The conspicuous negative $\mathrm{Nb}$ anomaly leads to the same conclusion, as it is usually explained (e.g., Bonjour and Dabard 1991; Slack and Stevens 1994) by the absence of the $\mathrm{Nb}$-rich anorogenic granites in the immature crust. The positive anomalies of $\mathrm{Ti}$, $\mathrm{Sc}, \mathrm{V}, \mathrm{Mg}, \mathrm{Cr}$ and $\mathrm{Ni}$ are indicative of variable mafic input from oceanic intraplate environment. The slight positive or negative "heavy mineral" anomalies of $\mathrm{Zr}$, $\mathrm{Hf}$ and Y probably point to sedimentary processes, such as density sorting during transport. The abovementioned characteristics are compatible with a prevailing continental island-arc source with a smaller variable admixture of oceanic mafic rocks and limited continental detrital material (e.g., Floyd et al. 1991). The problem of residual negative $\mathrm{Ca}$ and $\mathrm{Sr}$ anomalies remaining conspicuous even in the supposedly chemically little altered metagreywackes is still open. Jakeš et al. (1979) supposed an input of the spilitised basic volcanic detritus to solve the depletion in $\mathrm{Sr}$ in the Barrandian greywackes. The behavior of $\mathrm{Cu}$ is ambiguous and could be connected with depletions or enrichments due to mineralization processes.

A comparison of elemental distributions between the metamorphosed (TCC, KTB) and unmetamorphosed (BARR) greywackes does not reveal any substantial changes due to regional metamorphism. Moreover, similar distribution patterns of the TCC, BARR and KTB data suggest close genetic relations of the studied rocks from the mentioned units.

The REE distribution curves of the TCC samples form three principal groups. The major group of 26 samples (Fig. 9) displays pronounced negative Eu anomalies. According to McLennan et al. (1993), the negative Eu anomaly suggests that igneous rocks of the continentalisland arc provenance were formed by intra-crustal plagioclase fractionation. A comparison with the REE patterns of modern deep-sea turbidites (McLennan and Taylor 1991) shows a close similarity with those of continental island arcs.

The second group (Fig. 10) contains three samples and is without any Eu anomaly. Such pattern exists in andesites of both the continental and the oceanic-island arcs. The difference consists in a higher REE content and a steeper course of the distribution curve of CIA andesites compared to OIA settings (cf. Bhatia 1985; McLennan and Taylor 1991). This variation in REE patterns of CIA andesites depends on the degree of crystal differentiation during magma ascent, which is enhanced within the continental settings. 
Fig 11 Chondrite-normalized (Taylor and McLennan 1985) REE distribution in six metasedimentary rocks of the Teplá Crystalline Complex displaying positive $\mathrm{Ce}$ anomalies.

The third group containing six samples (Fig. 11) displays, besides Eu negative anomalies, also a distinct anomaly of $\mathrm{Ce}$. This feature can be attributed to LREE leaching during sedimentation under oxidizing conditions, whereby $\mathrm{Ce}^{4+}$ remains in the sediment (McDaniel et al. 1994).

Results of the $\mathrm{Rb}-\mathrm{Sr}$ and $\mathrm{Sm}-\mathrm{Nd}$ isotopic analyses presented in Fig. 12 distinguish two groups of geological units in the Bohemian Massif in the $\varepsilon_{\mathrm{Nd}}(\mathrm{T})$ vs. ${ }^{87} \mathrm{Sr} /{ }^{86} \mathrm{Sr}(\mathrm{T})$ plot. The first group containing TCC, KTB-VB, ZEV and Barrandian displays $\varepsilon_{\mathrm{Nd}}(\mathrm{T})$ values between -4 and +4 , the second one, containing Moldanubian and Saxothuringian samples,

Fig. 12 Variation fields in ${ }^{87} \mathrm{Sr} /{ }^{86} \mathrm{Sr}(\mathrm{T})$ vs. $\varepsilon_{\mathrm{Nd}}(\mathrm{T})$ binary plot for the Teplá Crystalline Complex and for comparable units. Data sources: this work, Liew and Hofmann (1988) von Drach and Köhler (1993) and Henjes-Kunst (2000).
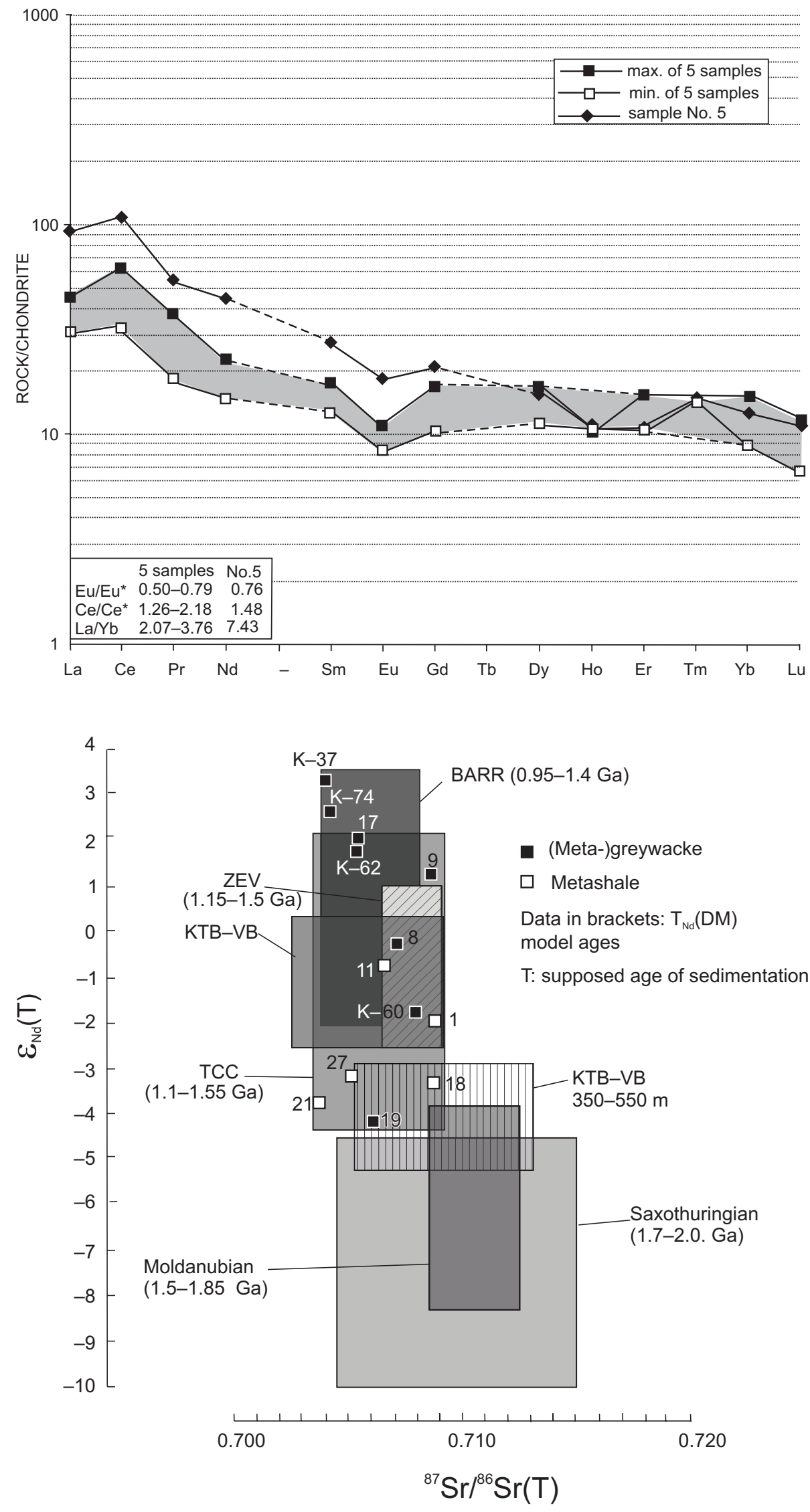
Tab. 6 Comparison of TCC metasediments and accretionary wedge sediments from Kamchatka (Russia), according Ledneva et al. (2004)

\begin{tabular}{|c|c|c|c|c|c|c|c|c|c|c|c|c|c|c|}
\hline & $\mathbf{N}$ & $\mathrm{K}_{2} \mathrm{O} / \mathrm{Al}_{2} \mathrm{O}_{3}$ & $\left(\mathrm{Fe}_{2} \mathrm{O}_{3}+\mathrm{MgO}\right) / \mathrm{SiO}_{2}$ & $\mathrm{Al}_{2} \mathrm{O}_{3} / \mathrm{SiO}_{2}$ & CIA & $\mathrm{Fe} / \mathrm{Mn}$ & $(\mathbf{L a} / \mathrm{Yb})_{\mathrm{N}}$ & $\mathbf{E u} / \mathbf{E u}$ * & $\mathrm{Ce} / \mathrm{Ce} *$ & $\mathbf{T h} / \mathbf{U}$ & $\mathrm{Th} / \mathrm{Sc}$ & $\mathrm{La} / \mathrm{Sc}$ & $\mathbf{R b} / \mathrm{Sr}$ & $\mathrm{Cr} / \mathrm{Ni}$ \\
\hline Teplá & 36 & 0.15 & 0.12 & 0.25 & 65.12 & 63.17 & 6.55 & 0.66 & 1.00 & 3.12 & 0.58 & 2.17 & 0.60 & 3.53 \\
\hline Kamchatka & 18 & 0.14 & 0.15 & 0.24 & 67.53 & 48.69 & 6.73 & 0.67 & 0.96 & 2.97 & 0.40 & 1.31 & 0.53 & 2.55 \\
\hline
\end{tabular}

falls within the interval of -4 to -10 . This difference evidently reflects the prevalence of rather juvenile material in the first group and, on the other hand, the prevalence of old evolved crustal material in the second one. This is supported by the lower model ages $\mathrm{T}_{\mathrm{Nd}}$ $(\mathrm{DM})=0.95-1.5 \mathrm{Ga}$ of the former group compared to those of the latter one $(1.5-2.0 \mathrm{Ga})$. Combining our data with those of Drost et al. (2007), we can follow on the Fig. 13 the gradual increase of the evolved continental crust component with the decreasing age of sediments. Our "K-" samples of unmetamorphosed Neoproterozoic greywackes represent the most primitive material of the whole Teplá-Barrandian sample set. Connecting the $\mathrm{Rb}-$ Sr systematics, all our samples plot outside the shaded zone; this indicates that no substantial late Rb-gain or Sr-loss occurred.

Our results of geochemical and isotopic investigations of the TCC metasediments point to their continental island-arc provenance. Štědrá et al. (2002) discussed two possible scenarios for geotectonic setting of the TCC: (1) a deeply reworked part of an accretionary wedge at a Gondwana margin, and (2) a subducted segment of an active continental margin with incorporated backarc slivers and metasedimentary and magmatic oceanic rocks. The hypothesis \#1 is (together with Zulauf 1997 and Dörr et al. 2002) one of the first suggestions of the accretionary wedge provenance in the Teplá-Barrandian. The results of geochemical and isotopic studies of Barrandian metabasalts (Pin and Waldhausrová 2007) sup- port this idea, further elaborated by Hajná et al. (2010) in the central and NW parts of this unit. In the current paper, we have attempted to evaluate this hypothesis using new geochemical data. The principal question, however, is to what degree can the two environments (i.e., the continental-island arc and the accretionary wedge) be unequivocally distinguished on the basis of difference in the geochemistry of sedimentary rocks.

To address this issue, we compare our results with a modern example of accretionary wedge sediments from Russian Kamchatka. There, a detailed geochemical study of Ledneva et al. (2004) documented the nature of the NE Asian active continental margin in the middle Eocene to early Miocene. The trace-element geochemistry of shales from the flysch and mélange indicates the derivation of this sediment types from an active continental margin and island arcs with partially dissected basement rocks. Such provenance characteristics are similar to those of the continental-island arc and, therefore, we can hardly expect any significant geochemical features to distinguish between the two geotectonic settings. The comparison of the TCC and the Kamchatka accretionary wedge points to their similar lithology (mostly flysch-like sediments and mélange). Regarding the principal geochemical features (some summarized in Tab. 6), the striking similarities include, e.g., the high LREE abundance, pronounced negative Eu anomaly, low $\mathrm{Th} / \mathrm{Sc}$ and $\mathrm{La} / \mathrm{Sc}$ ratios, negative $\mathrm{Nb}$ anomaly in relation to average upper crust etc. Small differences in some of the ratios can be explained
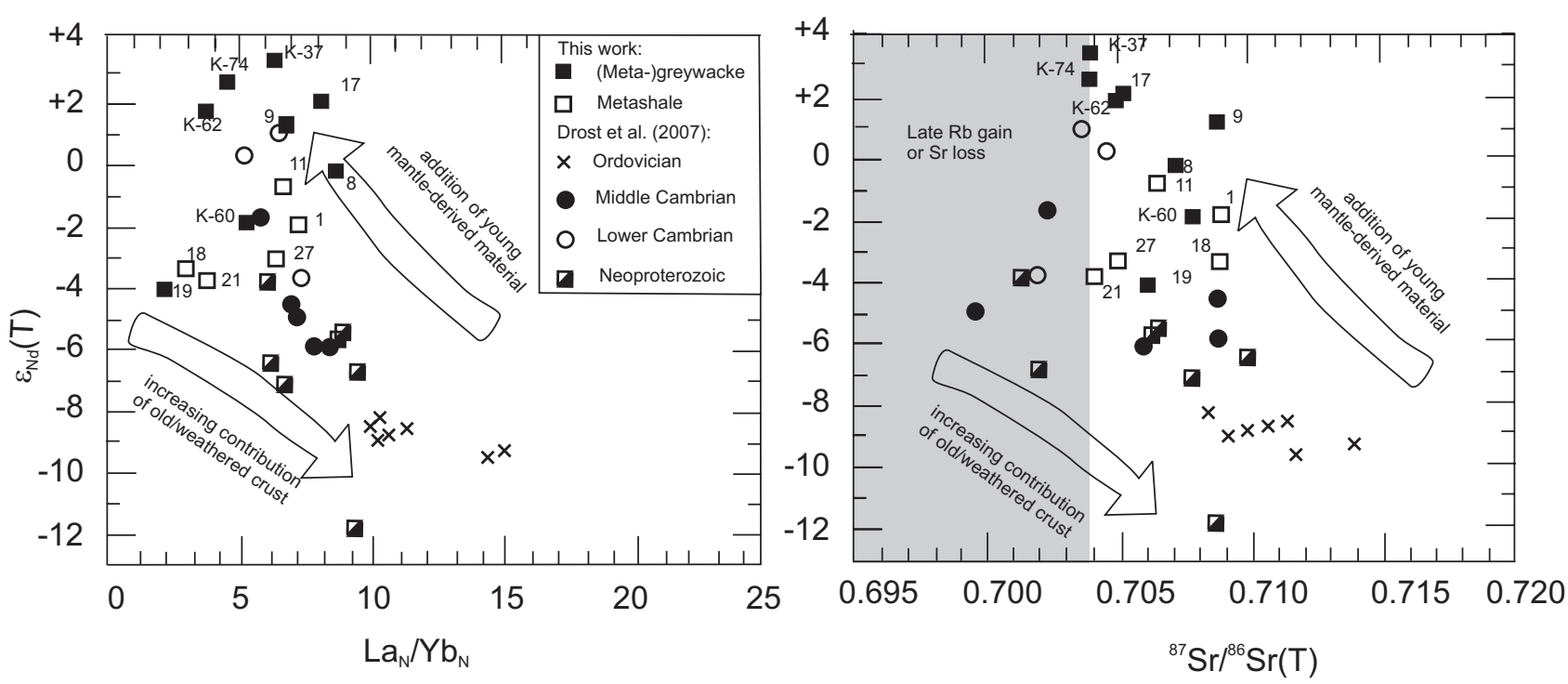

Fig. 13 Metasedimentary rocks of the Teplá Crystalline Complex in the binary diagram of Drost et al. (2007) involving Nd isotopic compositions. $\mathbf{a}-\mathrm{La}_{\mathrm{N}} / \mathrm{Yb}_{\mathrm{N}}$ vs. $\varepsilon_{\mathrm{Nd}}(\mathrm{T})$; Chondrite normalization after Taylor and McLennan (1985). b $-{ }^{87} \mathrm{Sr} /{ }^{86} \mathrm{Sr}(\mathrm{T}) \mathrm{vs} . \varepsilon_{\mathrm{Nd}}(\mathrm{T}) \mathrm{plot}$. 
by local variations, e.g., deep- or shallow-water conditions $(\mathrm{Fe} / \mathrm{Mn})$ and various admixtures of volcanic vs. ultramafic sources $(\mathrm{Cr} / \mathrm{Ni})$.

\section{Conclusions}

An extensive geochemical and $\mathrm{Sr}-\mathrm{Nd}$ isotopic investigation of the Teplá Crystalline Complex clastic metasedimentary rocks revealed their active continental margin affinity with an important role of underlying or nearby situated continental crust. Pure geochemical and isotopic criteria point to a relatively immature continental (ensialic) island arc. A comparison with the Tertiary accretionary wedge sedimentary complex (Kamchatka/Russia) shows striking geochemical similarities. The accretionary wedge idea is therefore consistent with a continental-arc provenance as derived from the rock geochemistry. The tectonic arguments and incompatibility of the Teplá-Barrandian metabasalts with their (meta-) sedimentary host represent further important constraints for the acceptance of the accretionary wedge provenance hypothesis for parts of the Neoproterozoic to early Cambrian sedimentary complexes of the Teplá-Barrandian Unit.

Acknowledgements. We are indebted to the Institute of Geology ASCR internal grant No. 9334 for the financial support to finishing this work. We also acknowledge the both anonymous reviewers for the critical useful comments and namely editors V. Janoušek and J. Žák for substantial improvement of the present paper. We are obliged to J. Adamovič for kind revision of English.

\section{References}

Beard BL, Medaris Jr LG, Johnson CM, Jelínek E, Tonika J, RiciPUTI LR (1995) Geochronology and geochemistry of eclogites from the Mariánské Lázně Complex, Czech Republic: implications for Variscan orogenesis. Geol Rundsch 84: 552-567

Bнatia MR (1983) Plate tectonics and geochemical composition of sandstones. J Geol 91: 611-627

BнAтіA MR (1985) Rare earth element geochemistry of Australian Paleozoic graywackes and mudrocks: provenance and tectonic control. Sediment Geol 45: 97-113

Bнatia MR, CROок KAW (1986) Trace element characteristics of graywackes and tectonic setting of sedimentary basins. Contrib Mineral Petrol 92: 181-193

Bonjour JL, Dabard MP (1991) Ti/Nb ratios of clastic terrigenous sediments used as an indicator of provenance. Chem Geol 91: 257-267

Bowes DR, Aftalion M (1991) U-Pb zircon isotopic evidence for early Ordovician and late Proterozoic units in the Mariánské Lázně Complex, Central European Hercynides. Neu Jb Mineral, Mh 7: 315-326

Cerrai E, Testa C (1963) Separation of rare earths by means of small columns of Kel-F supporting di(2-ethylhexyl) orthophosphoric acid. J Inorg Nucl Chem 25: 1045-1050

ČAdková Z, MrázeK P (1987) Trends of trace element distribution in several selected lithostratigraphic units of the Bohemian Massif. Cas Mineral Geol 32: 371-392 (in Czech with English summary)

Čadková Z, Jakeš P, HaKová M, MrázeK P (1985) Geochemical catalogue of the basic network. Unpublished database, Czech Geological Survey, Prague (in Czech)

Сна́в J (1978) Proposals of the lithostratigraphic and lithologic terminology for the Upper Proterozoic of the TepláBarrandian region. Věst Ústř Úst geol 53: 43-60 (in Czech)

Сна́в J, Pelc Z (1968) Lithology of Upper Proterozoic in the NW limb of the Barrandian area. Krystalinikum 6: 141-167

Сна́в J, Pelc Z (1973) Proterozoische Grauwacken im NW-Teil des Barrandiums (Tschechisch). Sbor geol V̌̌d 25: 7-84

CHÁB J, ŽÁČEK V (1994) Metamorphism of the Teplá Crystalline Complex. KTB Report 94-3: 33-37

Dallmeyer RD, Urban M (1998) Variscan vs. Cadomian tectonothermal activity in the northwestern sectors of the Teplá-Barrandian zone, Czech Republic: constraints from ${ }^{40} \mathrm{Ar} /{ }^{39} \mathrm{Ar}$ ages. Geol Rundsch 87: 94-106

DePaolo DJ, Linn AM, Schubert G (1991) The continental crustal age distribution: methods of determining mantle separation ages from $\mathrm{Sm}-\mathrm{Nd}$ isotopic data and application to the southwestern United States. J Geophys Res 96 B2: 2071-2088

Dörr W, Fiala J, Phillipe S, Vejnar Z, Zulauf G (1995) Cadomian vs. Variscan imprints in the Teplá-Barrandian Unit. - Part A: U-Pb ages of pre-Variscan granitoids. Terra Nostra 95: 91-92

Dörr W, Fiala J, Vejnar Z, Zulauf G (1998) U-Pb zircon ages and structural development of metagranitoids of the Teplá Crystalline Complex: evidence for pervasive Cambrian plutonism within the Bohemian Massif(Czech Republic) Geol Rundsch 87: 135-149

Dörr W, Zulauf G, Fiala J, Franke W, Vejnar Z (2002) Neoproterozoic to Early Cambrian history of an active plate margin in the Teplá-Barrandian Unit - a correlation of U-Pb isotopic-dilution-TIMS ages (Bohemia, Czech Republic). Tectonophysics 352: 65-85

Drost K, Linnemann U, McNaughton N, Fatka O, Kraft P, Gehmlich M, Tonk CH, MareK J (2004) New data on the Neoproterozoic-Cambrian geotectonic setting of the Teplá-Barrandian volcano-sedimentary successions: geochemistry, $\mathrm{U}-\mathrm{Pb}$ zircon ages, and provenance (Bohemian Massif, Czech Republic). Int J Earth Sci 93: 742-757

Drost K, Romer RL, Linnemann U, Fatka O, Kraft P, MAREK J (2007) Nd-Sr-Pb isotopic signatures of Neopro- 
terozoic-Early Paleozoic siliciclastic rocks in response to changing geotectonic regimes: a case study from the Barrandian area (Bohemian Massif, Czech Republic). In: Linnemann U, Nance RD, Kraft P, Zulauf G (eds) The Evolution of the Rheic Ocean: From AvalonianCadomian Active Margin to Alleghenian -Variscan Collision. Geological Society of America Special Papers 423: 191-208

Floyd PA, Leveridge BE (1987) Tectonic environment of the Devonian Gramscatho Basin, south Cornwall: framework mode and geochemical evidence from turbiditic sandstones. J Geol Soc, London 141: 531-542

Floyd PA, Shail R, Leveridge BE, Franke W (1991) Geochemistry and provenance of Rhenohercynian synorogenic sandstones: implications for tectonic environment discrimination. In: MORTON AC, TODd SP, Haughton PDW (eds) Developments in Sedimentary Provenance Studies. Geological Society London Special Publications 57: $173-188$

Glodny J, Grauert B, Fiala J, Vejnar Z, Krohe A (1998) Metapegmatites in the western Bohemian Massif: ages of crystallisation and metamorphic overprint, as constrained by $\mathrm{U}-\mathrm{Pb}$ zircon, monazite, garnet, columbite and $\mathrm{Rb}-\mathrm{Sr}$ muscovite data. Geol Rundsch 87: 124-134

Hajná J, Ž́́́ J, Kachlík V, Chadima M (2010) Subductiondriven shortening and differential exhumation in a Cadomian accretionary wedge: the Teplá-Barrandian Unit, Bohemian Massif. Precambrian Res 176: 27-45

HAJNÁ J, ŽÁK J, KACHLíK V (2011) Structure and stratigraphy of the Teplá-Barrandian Neoproterozoic, Bohemian Massif: a new plate-tectonic reinterpretation. Gondwana Res 19: 495-508

HajnÁ J, Ž́́́ J, Kachlík V, Chadima M (2012) Deciphering the Variscan tectonothermal overprint and deformation partitioning in the Cadomian basement of the Teplá-Barrandian Unit, Bohemian Massif. Int J Earth Sci (Geol Rundsch) 101: 1855-1873

Hajná J, ŽÁ́ J, Kachlík V, Dörr W, Gerdes A (2013) Neoproterozoic to early Cambrian Franciscan-type mélanges in the Teplá-Barrandian Unit, Bohemian Massif: evidence of modern-style accretionary processes along the Cadomian active margin of Gondwana? Precambr Res 224: 653-670

HenJes-Kunst F (2000) Isotopie. Abschlussbericht Mu 897/4 DFG-SPP "Orogene Prozesse" - Teil 4: 1-4. Unpublished report, BGR Hannover

Holubec J (1966) Stratigraphy of the Upper Proterozoic in the core of the Bohemian Massif (Teplá-Barrandian region). Rozpr Čs Akad Věd, ̌̌ mat prír Věd 76: 1-62

JaCOBSEN SB, WasSerburg GJ (1980) Sm-Nd isotopic evolution of chondrites. Earth Planet Sci Lett 50: 139-155

Jakeš P, Zoubek J, Zoubková J, Franke W (1979) Graywackes and metagraywackes of the Teplá-Barrandian Proterozoic area. Sbor geol Věd, Geol 33: 83-122
КаснLí́ V (1993) The evidence for Late Variscan nappe thrusting of the Mariánské Lázně Complex over the Saxothuringian terrane (W. Bohemia). J Czech Geol Soc 38: 46-58

KАснLі́́ V (1994) The Kladská Unit - petrological and structural evidence for Variscan thrusting of the Mariánské Lázně Complex over the Saxothuringian Terrane (West Bohemia). KTB Report 94-3: 19-31

KetTNeR R (1917) Versuch einer stratigraphischen Einteilung des Böhmischen Algonkiums. Geol Rundsch 8: 169-188

KošLer J, Bowes DR, Farrow CM, Hopgood AM, Rieder M, Rogers G (1997) Constraints on the timing of events in the multiepisodic history of the Teplá-Barrandian Complex, western Bohemia, from integration of deformational sequence and $\mathrm{Rb}-\mathrm{Sr}$ isotopic data. Neu Jb Mineral, $\mathrm{Mh}$ 1997: 203-220

Kratochvíl F, Vachtl J, ZoubeK V (1951) Geological relationships of the Křriženec-Nezdice Belt of the Teplá Upland. Sb Ústř Úst geol XVIII: 201-232 (in Czech)

KRETZ R (1983) Symbols for rock-forming minerals. Amer Miner 68: 277-279

Kreuzer H, Vejnar Z, Schüssler U, Okrusch M, Seidel E (1992) K-Ar dating in the Teplá-Domažlice Zone at the western margin of the Bohemian Massif. In: KuKaL Z (ed.) Proceedings of the $1^{\text {st }}$ International Conference on the Bohemian Massif. Czech Geological Survey, Prague, pp 168-175

KŘ́íbek B, Pouba Z, Skoček V, Waldhausrová J (2000) Neoproterozoic of the Teplá-Barrandian Unit as a part of the Cadomian orogenic belt: a review and correlation aspects. Bull Geosci 75: 175-196

LANG M (2000) Composition of Proterozoic greywackes in the Barrandian. Bull Geosci 75: 205-216

Ledneva GV, Garver JI, Shapiro MN, Lederer J, Brandon MT, HoLLOCHER KT (2004) Provenance and tectonic settings of accretionary wedge sediments on northeastern Karaginski Island (Kamchatka, Russian Far East). Russian J Earth Sci 6: 105-132

Liew TC, Hofmann AW (1988) Precambrian crustal components, plutonic associations, plate environment of the Hercynian Fold Belt of central Europe: indications from a Nd and Sr isotopic study. Contrib Mineral Petrol 98:129-138

MAŠEK J (2000) Stratigraphy of the Proterozoic of the Barrandian area. Bull Geosci 75:197-200

MAŠEK J, ZoubeK J (1980) Proposal of stratigraphical terms for stratigraphical units of the Barrandian Proterozoic. Věst Ústř Úst geol 55: 121-123 (in Czech)

MATĚJKA D (1988) Geochemistry of Upper Proterozoic rocks of the Svojšín volcanic strip (Western Bohemia) and problem of the source material of metasediments. Geol Carpath 39: 109-122

Matte P, Maluski H, Rajlich P, Franke W (1990) Terrane boundaries in the Bohemian Massif: result of large-scale Variscan shearing. Tectonophysics 177: 151-170 
McDaniel D, Hemming S, McLennan S, Hanson G (1994) Resetting of neodymium isotopes and redistribution of REEs during sedimentary processes: the Early Proterozoic Chelmsford Formation, Sudbury Basin, Ontario, Canada. Geochim Cosmochim Acta 58: 931-941

McLennan SM, Taylor SR (1991) Sedimentary rocks and crustal evolution: tectonic setting and secular trends. J Geol 99: 1-21

McLennan SM, Hemming S, McDaniel DK, Hanson GN (1993) Geochemical approaches to sedimentation, provenances and tectonics. In: JoHNSSON MJ, BAsu A (eds) Processes Controlling the Composition of Clastic Sediments. Geological Society of America Special Papers 284: $21-40$

MrÁzeK P (1984) Minor and trace elements in rocks of the Bohemian Upper Proterozoic. Sbor geol Věd, ložisk Geol Mineral 26: 81-104 (in Czech with English summary)

MüLLER H (1989) Geochemistry of metasediments in the Hercynian and pre-Hercynian crust of the Schwarzwald, the Vosges and Northern Switzerland. Tectonophysics 157: 97-108

Nesbitt HW, Young GM (1982) Early Proterozoic climate and plate motions inferred from major element chemistry of lutites. Nature 299: 715-717

Norrish K, Chappell BW (1977) X-ray Fluorescence Spectrometry. In: Zussman J (ed) Physical Methods in Determinative Mineralogy, $2^{\text {nd }}$ edition. Academic Press, London, pp 201-272

Pin C, Waldhausrová J (2007) Sm-Nd isotope and trace element study of Late Proterozoic metabasalts ("spilites") from the Central Barrandian domain (Bohemian Massif, Czech Republic). In: Linnemann U, Nance RD, KRAFt P, Zulauf G (eds) The Evolution of the Rheic Ocean: From Avalonian-Cadomian Active Margin to Alleghenian-Variscan Collision. Geological Society of America Special Papers 423: 231-247

Povondra P, Šulcek Z, Doležal J (1968) Decomposition Techniques in Inorganic Analysis. Elsevier, Amsterdam, pp 1-224

RöHLıch P (1965) Geologische Probleme des mittelböhmischen Alginkiums. Geologie 14.4: 373-403

RöHLICH P (2000) Some stratigraphic problems of the Barrandian Neoproterozoic. Bull Geosci 75: 201-204

Slack JF, Stevens PJ (1994) Clastic metasediments of the Early Proterozoic Broken Hill Group, New South Wales, Australia: geochemistry, provenance, and metallogenic significance. Geochim Cosmochim Acta 58: 3633-3652

ŠTĚDRÁ V, KACHLíK V, KRYZA R (2002) Coronitic metagabbros of the Mariánské Lázně Complex and Teplá Crystalline Unit: inferences for the tectonometamorphic evolution of the western margin of the Teplá-Barrandian Unit, Bohemian Massif. In: Winchester JA, Pharaoh TC, Verniers $\mathrm{J}$ (eds) Palaeozoic Amalgamation of Central Europe. Geological Society London Special Publications 201: 217-236
Steiger RH, JÄGER E (1977) Subcommission on geochronology: convention on the use of decay constants in geo- and cosmochronology. Earth Planet Sci Lett 36: 359-362

TAYlor SR, McLennan SM (1985) The Continental Crust: Its Composition and Evolution. Oxford, Blackwell, pp 1-312

Timmermann H, Štědrá V, Gerdes A, Noble SR, Parrish RR, DöRR W (2004) The problem of dating high-pressure metamorphism: a U-Pb isotope and geochemical study on eclogites and related rocks of the Mariánské Lázně Complex, Czech Republic. J Petrol 45: 1311-1338

Timmermann H, Dörr W, Krenn E, Finger F, Zulauf G (2006) Conventional and in situ geochronology of the Teplá Crystalline unit, Bohemian Massif: implications for the processes involving monazite formation. Int J Earth Sci (Geol Rundsch) 95: 629-647

Vejnar Z, Zoubek V (1962) Explanations to Geological Map of the ČSSR 1:200 000, sheets M-33-XIX Mariánské Lázně and M-33-XXV Švarcava. Czech Geological Survey, Prague (in Czech)

von Drach V, KöHLer H (1993) Geochronologisches Profil der KTB-Vorbohrung. KTB-Report 93-2: 385-388

WÄnke H, Dreibus G, Jagoutz E (1984) Mantle chemistry and accretion history of the Earth. In: KRÖNER A, HANsON GN, Goodwin AM (eds) Archaean Geochemistry. Springer-Verlag, Berlin, pp 2-24

WeBER K, BEHR HJ (1983) Geodynamic interpretation of the Mid-European Variscides. In: Martin H, Eder W (eds) Intracontinental Fold Belts - Case Studies in the Variscan Belt of Europe and the Damara Orogen of Namibia. Springer, New York, pp 427-469

Weber K, Vollbrecht A (1986) Kontinentales Tiefbohrprogramm der Bundesrepublik Deutschland. Ergebnisse der Vorerkundungsarbeiten, Lokation Oberpfalz. In: Second KTB Kolloquium, Seeheim/Odenwald, pp 1-186

WimMEnAuER W (1984) Das prävariskische Kristallin im Schwarzwald. Fortschr Miner 62: Bh. 2, 69-86

WimMEnAUER W (1991) Geochemie der metamorphen Sedimentgesteine in der Kontinentalen Tiefbohrung und ihrem Umfeld. KTB-Report 91-1: 106-135

Zulauf G (1997) Von der Anchizone bis zur Eklogitfazies: Angekippte Krustenprofile als Folge der cadomischen und variscischen Orogenese im Teplá-Barrandium (Böhmische Masse). Geotekt Forsch 89: 1-302

Zulauf G, Fiala J, Finger F, Linnemann U (2004) Cadomian orogenic imprints in the Bohemian Massif (Austria, the Czech Republic and Germany). Field Trip Guide Book - B31. 32 $2^{\text {nd }}$ International Geological Congress, Florence, pp 1-44

ŽÁČEK V (1994) Garnets and metamorphic evolution of the Teplá Crystalline Complex, Western Bohemia. Zbl Geol Paläont Teil I, 7/8: 847-856

ŽÁČEK V, СНА́B J (1993) Metamorphism in the Teplá Upland, Bohemian Massif, Czech Republic (preliminary report). Věst Čes geol Úst 68: 33-37 